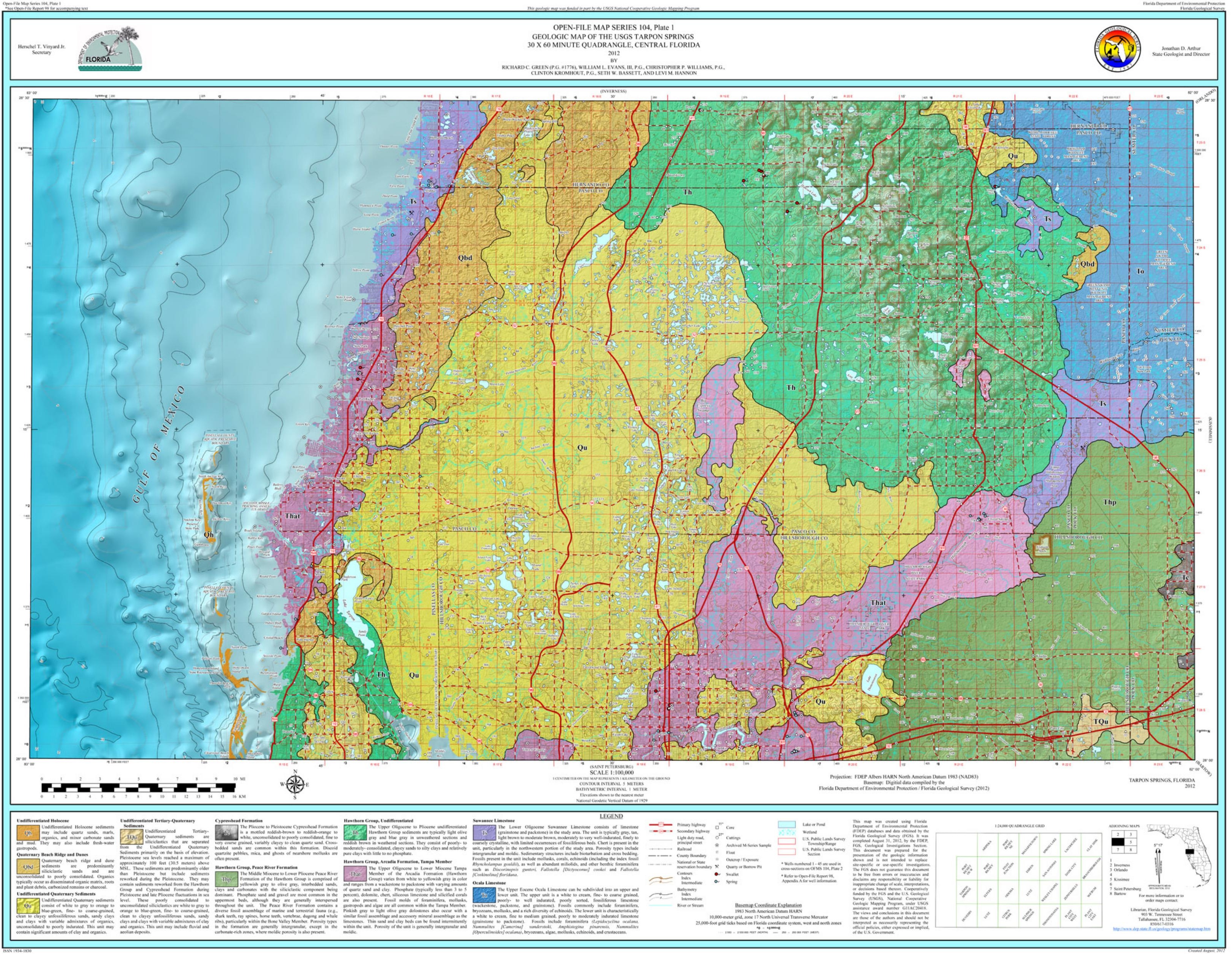




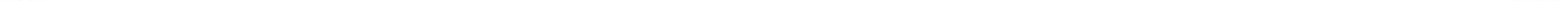




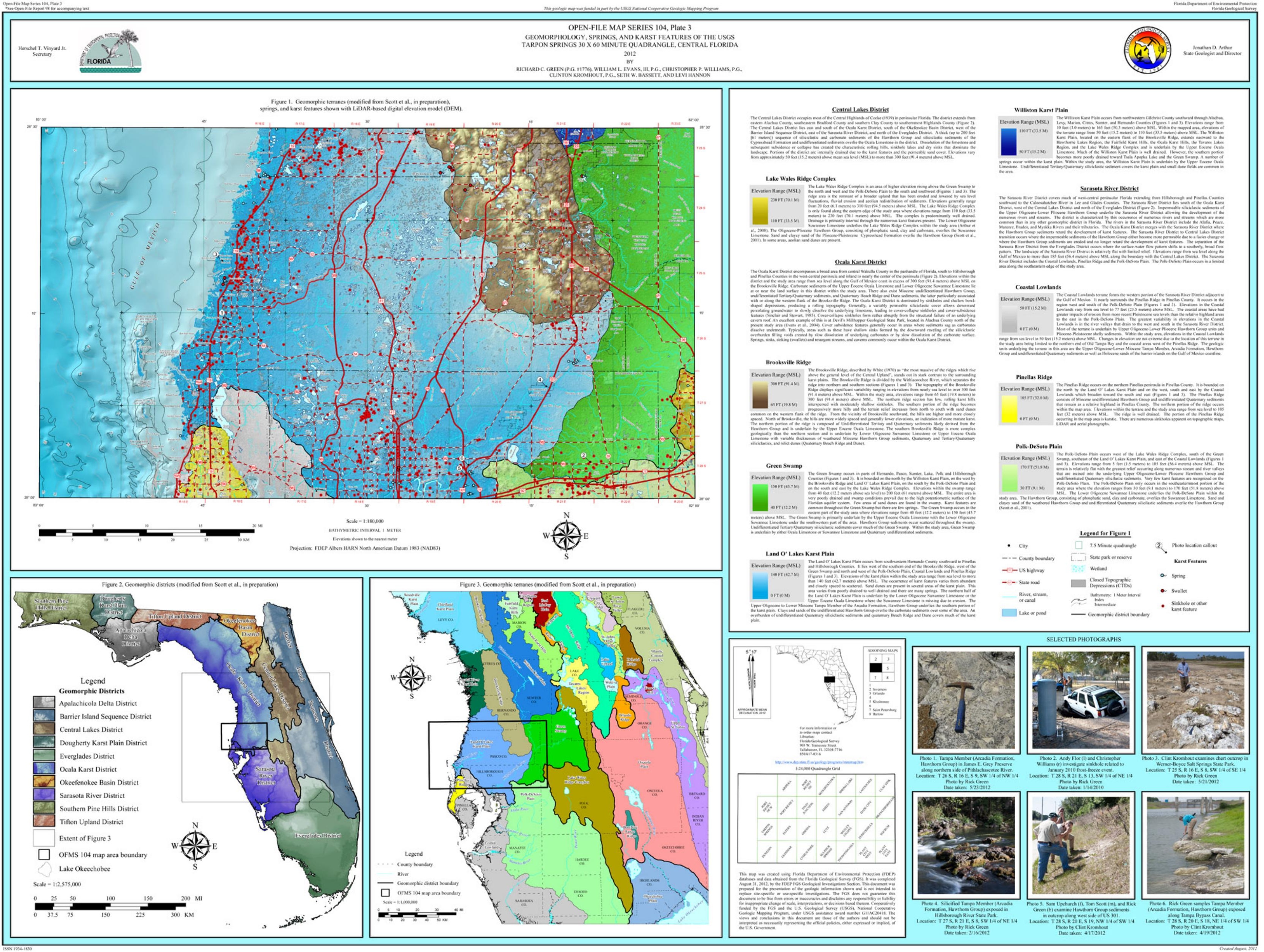




\section{STATE OF FLORIDA}

\section{DEPARTMENT OF ENVIRONMENTAL PROTECTION}

Herschel T. Vinyard Jr., Secretary

\section{REGULATORY PROGRAMS}

Jeff Littlejohn, Deputy Secretary

\section{FLORIDA GEOLOGICAL SURVEY}

Jonathan D. Arthur, State Geologist and Director
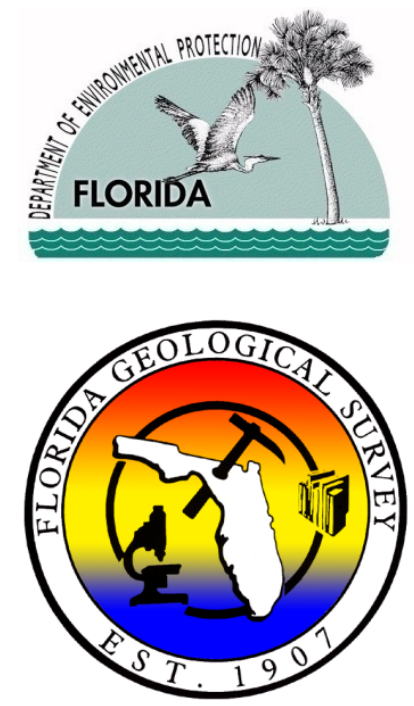

OPEN-FILE REPORT 98

Text to accompany geologic map of the USGS Tarpon Springs 30 x 60 minute quadrangle, central Florida

\section{By}

Richard C. Green, William L. Evans, III, Christopher P. Williams, Clinton Kromhout and Seth W. Bassett

2012

ISSN (1058-1391)

This geologic map was funded in part by the USGS National Cooperative Geologic Mapping Program under assistance award number G11AC20418 in Federal fiscal year 2011 


\section{TABLE OF CONTENTS}

ABSTRACT

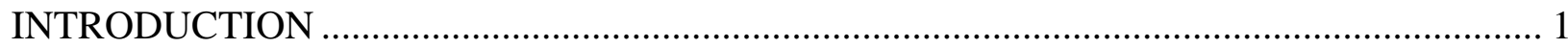

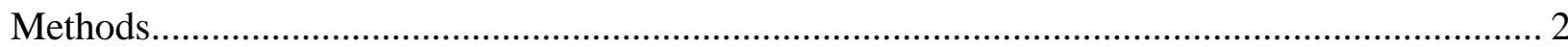

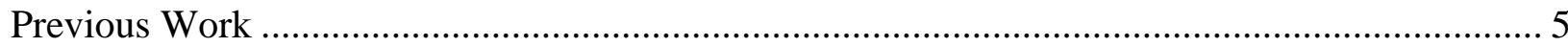

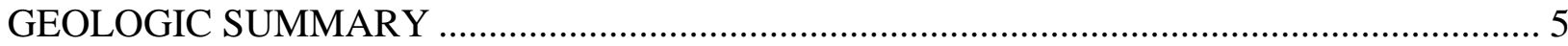

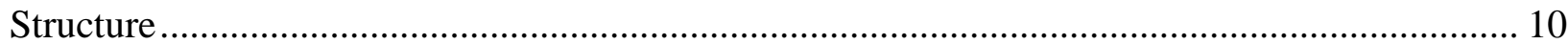

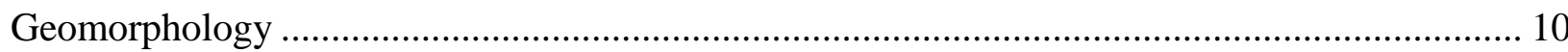

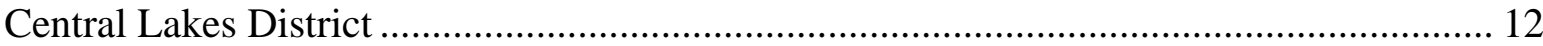

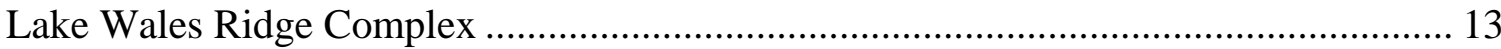

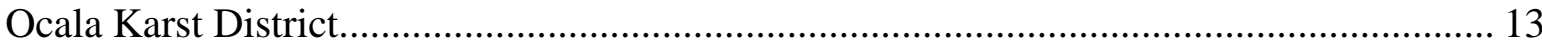

Brooksville Ridge …………………………………........................................ 14

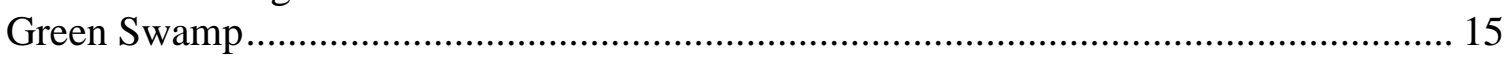

Land O’ Lakes Karst Plain........................................................................................ 15

Williston Karst Plain............................................................................................. 15

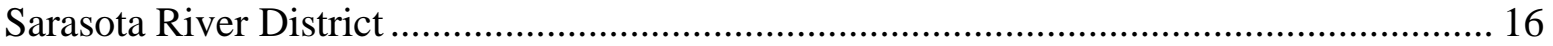

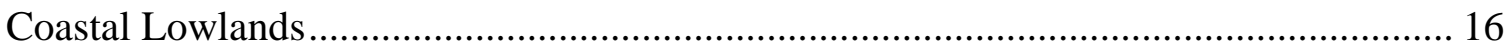

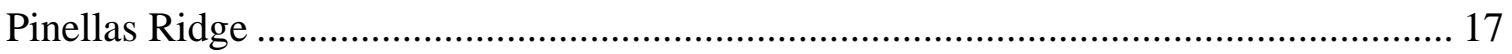

Polk-DeSoto Plain.................................................................................................... 17

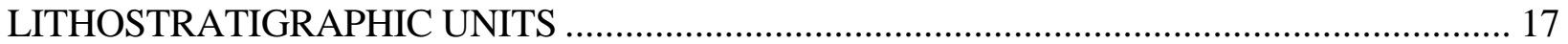

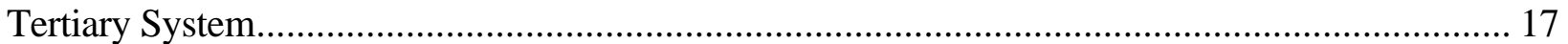

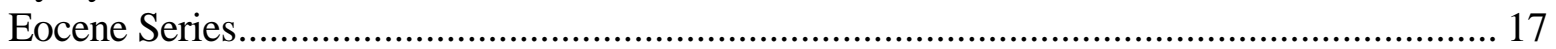

Avon Park Formation................................................................................................ 17

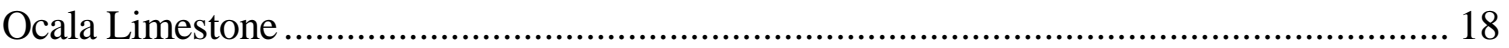

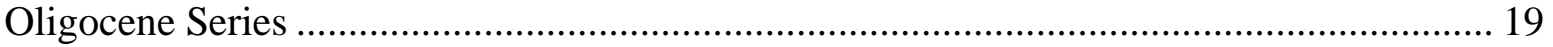

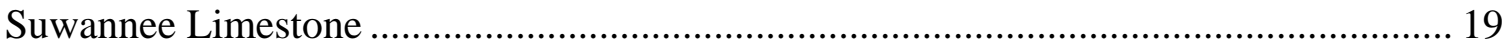

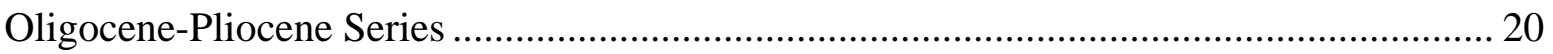

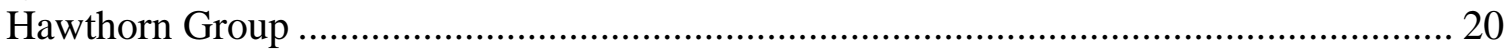

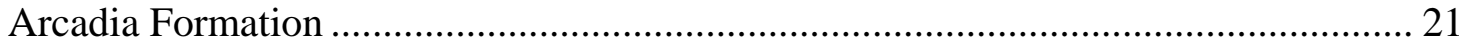

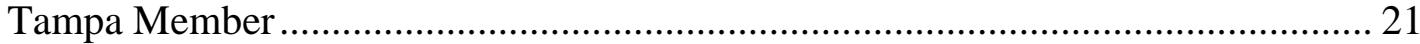

Peace River Formation.............................................................................................. 22

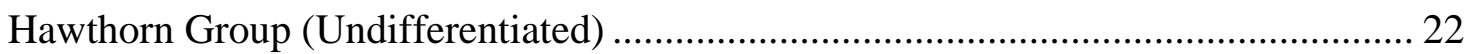

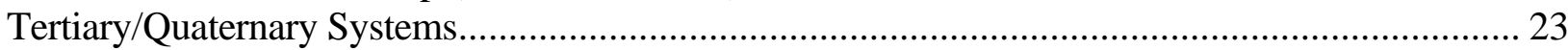

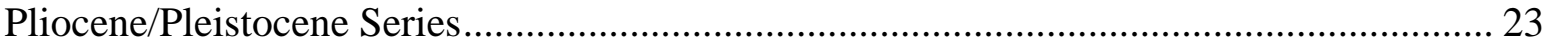

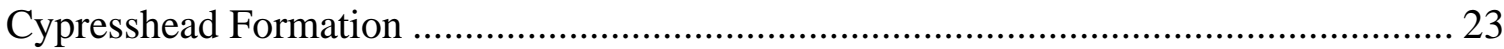

Undifferentiated Tertiary/Quaternary Sediments …………………………………..... 24

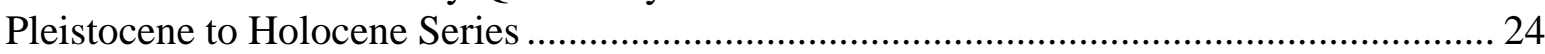

Undifferentiated Quaternary Sediments .............................................................. 24

Quaternary Beach Ridge and Dune............................................................................... 25

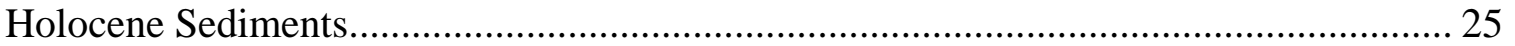

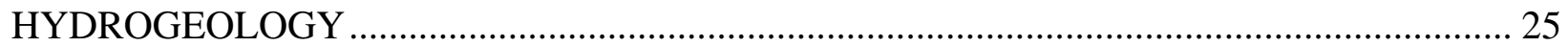

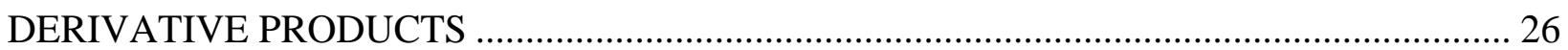

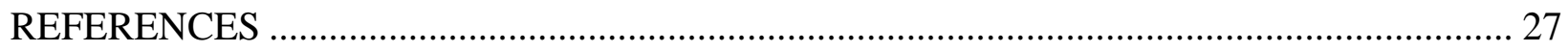

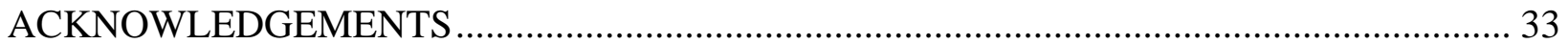

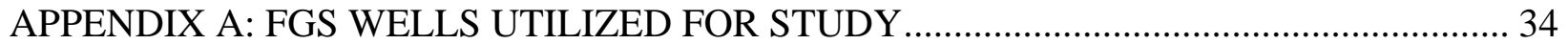




\section{LIST OF FIGURES}

Figure 1. Nearby areas mapped under the FGS STATEMAP Program. ..................................... 3

Figure 2. FGS cores and cuttings, consultant boring data, M-series samples, and Southwest

Florida Water Management District water well data utilized for top of rock model.......... 4

Figure 3. Location of selected river basins, springs, swallets and other water bodies. ................ 7

Figure 4. Principal subsurface structures of North Florida (modified from Puri and Vernon, 1964

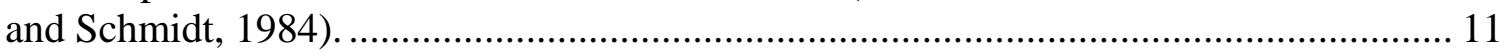

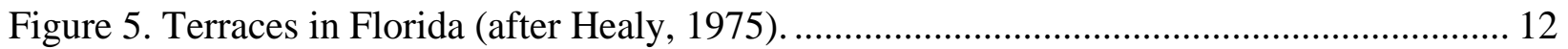




\title{
Text to accompany geologic map of the USGS Tarpon Springs 30 x 60 minute quadrangle, central Florida
}

\author{
Richard C. Green (P.G. \# 1776), William L. Evans, III, Christopher P. Williams, Clinton \\ Kromhout and Seth W. Bassett
}

\begin{abstract}
The accompanying 1:100,000 scale geologic map (Open-File Map Series 104, Plate 1) depicts the areal distribution of bedrock and surficial geologic units for the U.S. Geological Survey (USGS) Tarpon Springs 30 x 60 minute quadrangle. The map was constructed using a combination of field mapping (at 1:24,000 scale), compilation of data from existing maps (various scales), core and cuttings analyses and descriptions, and analyses of various Geographic Information System (GIS) data sources. The resulting data were compiled in ESRI ${ }^{\circledR}$ ArcGIS $^{\circledR}$ ArcMap $^{\mathrm{TM}} 10$ software for publication as part of the Florida Geological Survey Open-File Map Series. Mapped units range from Upper Eocene to Quaternary. Important resources in the mapped area include potable groundwater, springs, sand, clay, phosphate and limestone. Numerous springs, swallets (sinking streams), and other karst features are present in the study area. The geologic maps produced for this area not only provide a greater understanding of the interaction between the geologic units, associated karst, springs and ecosystems, but have utility as a land management tool for economic development, mineral and energy production, and environmental protection for Florida. Examples include designing new construction projects, siting new water supply wells, energy production facilities, waste management and storage facilities, locating sources of mineable resources for aggregate supply, and protection of springs, surface and groundwater quality.
\end{abstract}

Keywords: Florida, geologic map, Avon Park Formation, Ocala Limestone, Suwannee Limestone, Hawthorn Group, Arcadia Formation, Tampa Member, Peace River Formation, Cypresshead Formation, geomorphology, hydrogeology, springs, swallets, karst, sinkholes, Floridan aquifer system, Hernando County, Hillsborough County, Pasco County, Pinellas County, Polk County, Sumter County, Brooksville Ridge.

\section{INTRODUCTION}

The Florida Geological Survey (FGS) Open-File Report (OFR) 98 accompanies OpenFile Map Series (OFMS) 104, which is comprised of three plates. Plate 1 depicts the nearsurface geology of the USGS Tarpon Springs 30 x 60 minute quadrangle (U.S. Geological Survey, 1978) on a light detection and ranging (LiDAR) digital elevation model (DEM). Plate 2 depicts six geologic cross-sections, a stratigraphic correlation chart, and representative photos for several of the lithologic units in the study area. Plate 3 is a geomorphology map on a LiDAR DEM, showing locations of known springs, sinkholes and swallets, along with photographs of selected exposures within the study area.

The study area lies south of Inverness and north of Tampa. It includes the communities of Plant City, Zephyrhills, Temple Terrace, Dunedin, Tarpon Springs, and New Port Richey. It includes portions of Hernando, Hillsborough, Sumter, Pinellas and Polk Counties, as well as all of Pasco County (Figure 1). It is bounded to the north by the USGS Inverness $30 \times 60$ minute 
quadrangle, recently mapped under the STATEMAP program (Green et al., 2011; Williams et al., 2012; Williams et al., 2011; Williams and Green, 2012), to the south by the USGS Saint Petersburg $30 \times 60$ minute quadrangle and to the east by the USGS Kissimmee 30 × 60 minute quadrangle (Figure 1). The northern edge of Tampa Bay, the Hillsborough, Pithlachascotee and Anclote Rivers, along with numerous creeks and springs occur in the map area. Recharge to and discharge from the Floridan aquifer system (FAS) occurs throughout the study area. The FAS is the primary source of water for springs and drinking water in the region.

One objective for this report is to provide basic geologic information for the accompanying OFMS 104. Information provided by this report and the plates in OFMS 104 is intended for a diverse audience of professionals in geology, hydrology, engineering, environmental and urban planning, and laypersons, all of whom have varying levels of geologic knowledge. The maps can help users identify and interpret geologic features which impact activities related to groundwater quality and quantity, as well as aid in locating mineral resources, land-use planning and construction project design. Applied uses of the maps and data in this report include: 1) identifying potential new mineral resources, 2) characterizing zones of potential aquifer recharge and confinement, 3) aiding water-management decisions on groundwater flow and usage, 4) providing information on aquifer vulnerability to potential pollution, 5) ecosystem, wetlands and environmental characterization, and 6) recreational uses.

\section{Methods}

Mapping efforts consisted of: 1) reviewing and compiling existing geologic literature and data, 2) mapping geologic units in the field at 1:24,000 scale using standard techniques, 3) analyses of existing core and cuttings samples from the FGS sample repository, 4) new core drilling, 5) collecting and describing outcrop samples, and 6) preparing a geologic map, geological cross-sections and geomorphic map of the area. Field work, performed during the fall of 2011 through the summer of 2012, consisted of sampling and describing numerous outcrops, and river and quarry exposures.

Ninety-eight new samples of geologic material were added to the FGS surface-sample archives (M-Series) and two cores (779 feet or 237.4 meters total) were drilled. Approximately 150 outcrops and exposures were also examined during this project. All data, including over 800 wells from the study area and surrounding quads, were compiled and analyzed by the authors. Figure 2 shows the locations of FGS cores and cuttings, consultant boring data, M-series samples, and Southwest Florida Water Management District (SWFWMD) water well data points within the study area. Appendix A includes FGS wells with core and/or cuttings samples inside the boundaries of the Tarpon Springs quadrangle which were examined by the authors and used for the top of rock model and for determining the geologic surface and subsurface formations. An interpolated top of rock surface was developed using kriging along with a LiDAR-derived Digital Elevation Model (DEM) to generate an overburden thickness model. The map and accompanying plates were developed in ESRI ${ }^{\circledR}$ ArcGIS $^{\circledR}$ ArcMap $^{\text {TM }} 10$ software for publication as part of OFMS 104.

A total of 10,671 points located in or near the Inverness and Tarpon Springs 30 x 60 minute quadrangles were used to generate a top of rock model for the study area. Each of these points indicated the depth below land surface of the first lithified carbonate units. The points came from one of four datasets: 878 points were cores or cuttings in the possession of the FGS 


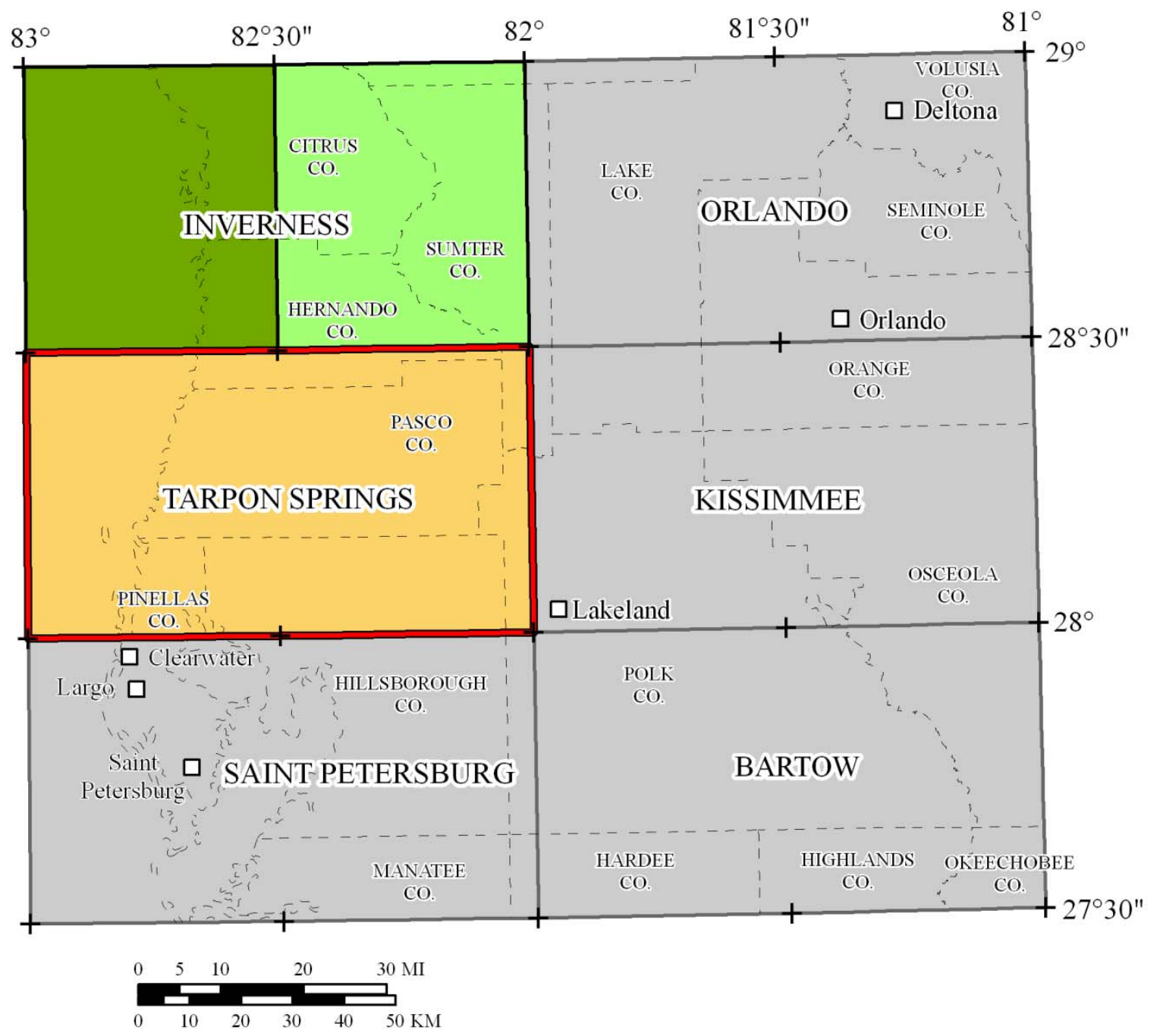

\section{LEGEND}
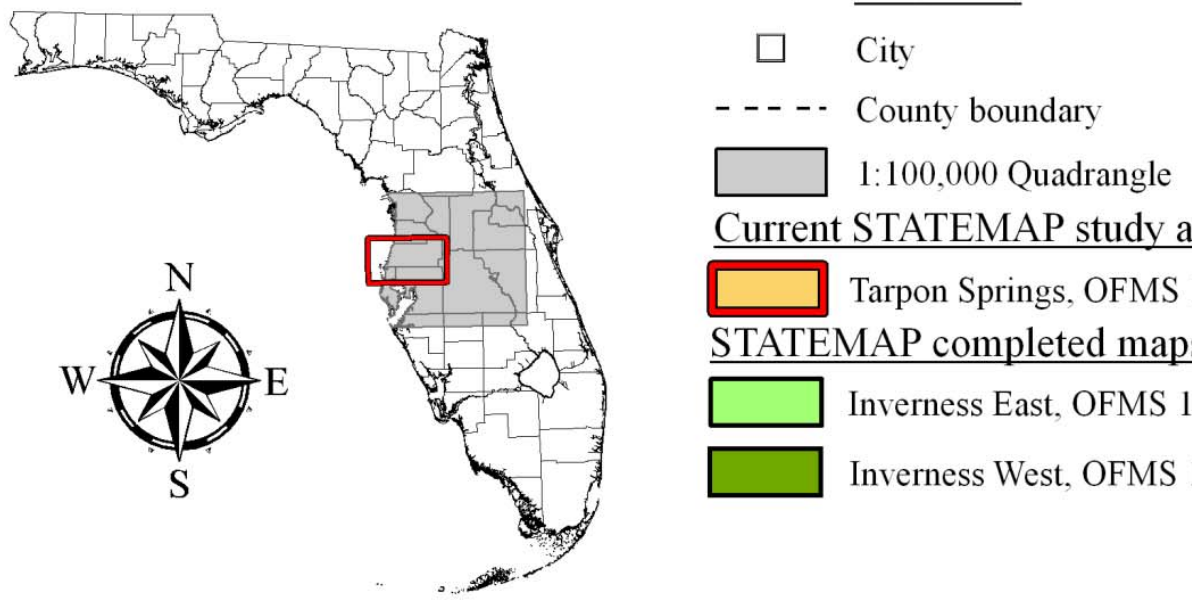

Current STATEMAP study area

Tarpon Springs, OFMS 104, 2012

STATEMAP completed maps

Inverness East, OFMS 102, 2011

Inverness West, OFMS 103, 2012

Figure 1. Nearby areas mapped under the FGS STATEMAP Program. 


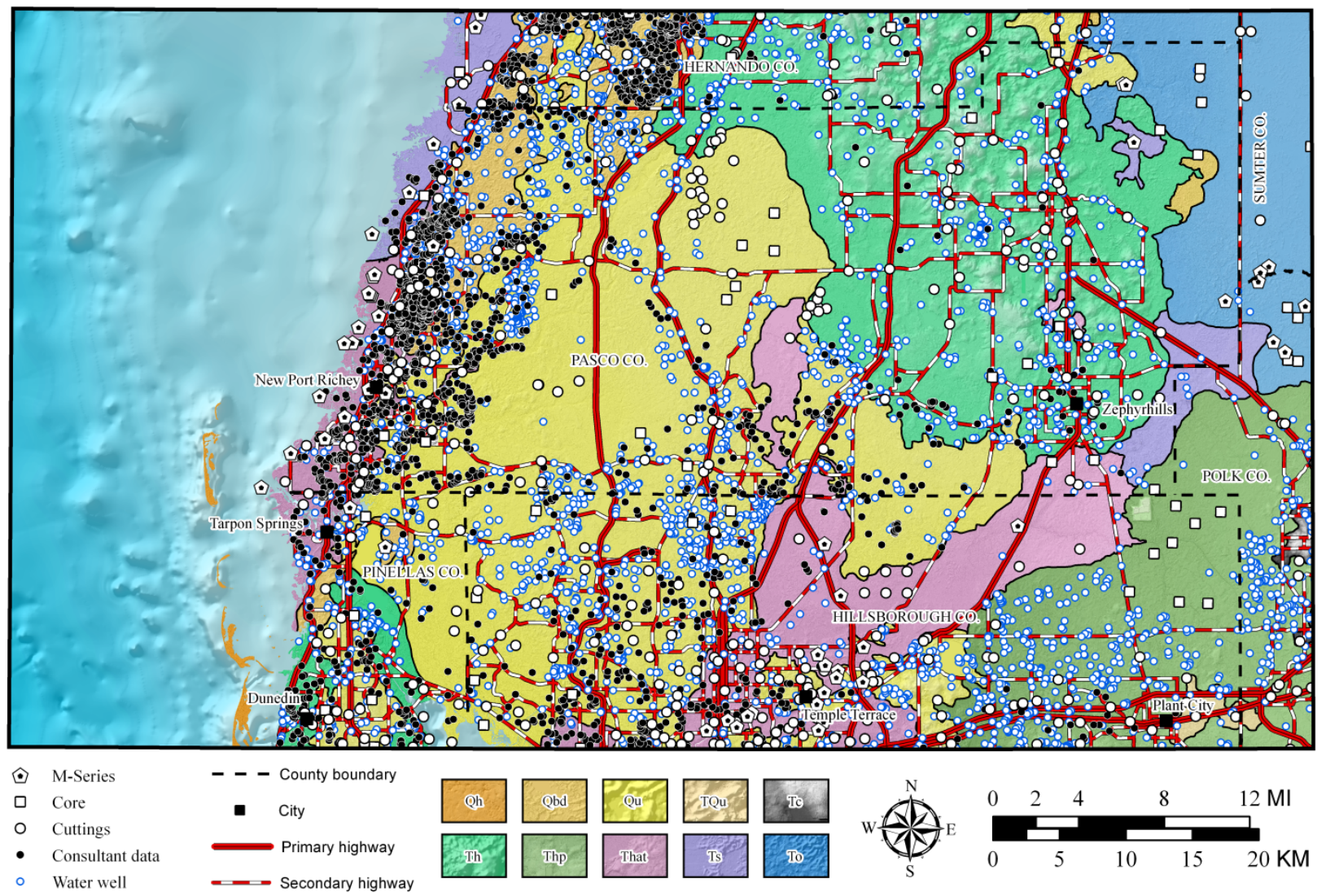

Figure 2. FGS cores and cuttings, consultant boring data, $M$-series samples, and Southwest Florida Water Management District water well data utilized for top of rock model. See discussion starting on page 17 for lithostratigraphic unit abbreviations and descriptions.

that were examined by a geologist, 85 points were M-Series samples of carbonate outcrops found at land surface by field teams, 2,860 points were obtained from consultant boring data (indicating the depth to carbonate at each location), and 6,848 points were obtained from SWFWMD well data indicating the depth of the first carbonate units.

As a preliminary step, all of the available points from each of the four datasets were used to generate a Triangular Irregular Network (TIN) of the rock surface. This TIN was then used as a method of examining and discarding any points that appeared anomalous compared to their surrounding values. During this step, any point which differed substantially from the surrounding points were indicated by a sharp depression or peak in the TIN surface; points found that differed by 75 or more feet from surrounding points were then removed from the dataset.

After this step was completed, an ordinary kriging method was used to generate a top of rock surface using the "stable" algorithm. Lag size was empirically calculated based on the total spatial extent of the combined datasets, and then adjusted slightly to improve model performance. The error values for all data were examined after each iteration of the model, and any points with a standardized error greater than five or less than negative five were discarded in order to improve the final model performance.

Much of the study area is blanketed by a veneer of undifferentiated Tertiary and Quaternary sediments and soils. For this reason, and in keeping with geologic mapping practices developed by Scott et al. (2001), the authors have adopted the policy of mapping the first named 
geologic unit within 20 feet (6.1 meters) of the surface. If undifferentiated Tertiary/Quaternary (TQu), undifferentiated Quaternary (Qu), Holocene (Qh) or Quaternary Beach Ridge and Dune (Qbd) sediments attain a thickness greater than 20 feet (6.1 meters), then they appear as the mapped unit. If these undifferentiated sediments are less than 20 feet (6.1 meters) thick, then the underlying lithostratigraphic unit appears on the map.

Parts of the region are heavily vegetated, and public access in parts of the mapped area is hindered by the presence of numerous wetlands, farms, ranches and privately owned land. Additionally, much of the coastal area is heavily developed with sub-divisions, many of which are gated communities. In instances where access was limited by these factors, the authors had to rely on existing well and core data. Fieldwork access was typically limited to public roads, State-owned lands and County-owned lands.

\section{Previous Work}

The current study builds on many previous geologic investigations in and around the present map area which were useful in preparing this report. Preliminary county geologic maps for Hernando (Campbell, 1993a), Hillsborough (Campbell and Arthur, 1993), Pasco (Arthur, 1993), Pinellas (Arthur and Campbell, 1993), Polk (Campbell, 1993b) and Sumter (Campbell, 1993c) Counties at 1:126,720 scale were previously published by the FGS. However, each of these OFMS geologic maps were constructed in an average time-frame of two weeks utilizing selected in-house geologic data with little-to-no extra field work. Although these maps provided a starting point for the detailed geologic mapping undertaken for this project, significant refinement of prior geologic maps was possible as a result of this project. A statewide geologic map (Scott et al., 2001) was published by the FGS in digital format and provided a framework for the current, more detailed mapping.

Yon and Hendry (1972) studied the distribution of the Suwannee Limestone in Hernando and Pasco Counties. Scott (1988) published detailed descriptions, structure contour maps, and isopach maps for units of the Hawthorn Group. Arthur et al., (2008) provided structure contour and isopach maps of all of the major units investigated in this study.

This study benefited greatly from the work performed during geologic mapping of the eastern portion of the USGS Inverness 30 x 60 minute quadrangle (Green et al., 2011; Williams et al., 2011) and the western portion of the USGS Inverness 30 x 60 minute quadrangle (Williams et al., 2012; Williams and Green, 2012). Some of the field relationships and stratigraphic problems were worked out during those projects and data gathered during work on them proved invaluable to the completion of this project.

\section{GEOLOGIC SUMMARY}

The near surface geology of the USGS $30 \times 60$ minute Tarpon Springs quadrangle is composed of a complex mixture of Middle Eocene to Quaternary carbonate and siliciclastic sediments. A combination of factors, including fluvio-deltaic deposition, marine deposition, dissolution of underlying carbonates (karstification), erosion of sediments as a result of eustatic changes in sea level and structural features have influenced the geology of the study area.

The oldest unit to crop out in the Tarpon Springs quadrangle is the Upper Eocene Ocala Limestone. This can be seen in outcrop at various locations in the northeastern portion of the map area. The Lower Oligocene Suwannee Limestone, which unconformably overlies the Ocala Limestone, crops out in the coastal plain near the Gulf of Mexico in the northwestern portion of 
the study area. Outcrops of the Suwannee Limestone also occur in areas to the south and east of the Brooksville Ridge (OFMS 104, Plate 1). The Upper Oligocene Tampa Member of the Arcadia Formation (Hawthorn Group) unconformably overlies the Suwannee Limestone and crops out along the western edge of the map area and in south-central portions of Pasco and Hillsborough Counties in the Hillsborough River corridor, as well as in the vicinity of State Road 589 along the southern border of the quadrangle (OFMS 104, Plate 1). The Middle Miocene to Lower Pliocene Peace River Formation (Hawthorn Group), which unconformably overlies the Tampa Member, crops out in the southeastern portion of the study area. Sediments of undifferentiated Oligocene to Pliocene Hawthorn Group overlie the Tampa Member in the southwestern portion of the map area and southern portions of the Brooksville Ridge and the Suwannee Limestone in the northern portion of the Brooksville Ridge within the study area (OFMS 104, Plates 1 and 2).

The top of limestone surface is highly variable in this region. When the Suwannee Limestone is present, it is underlain by the Ocala Limestone throughout the study area. These two formations can both vary from wackestone to grainstone. Current authors and others (Brewster-Wingard et al., 1997) have noted that, lithologically, the contact between the Suwannee Limestone and the Ocala Limestone can be difficult to differentiate in cores and cuttings. At times there is a distinct contact between the two formations; however, this is not always the case. This becomes particularly problematic in the northeastern portion of the map area where the Suwannee Limestone is thin and erosion, dissolution, and silicification have worked together to make differentiation of the two formations difficult.

Detailed description of the lithology of all units found in the study area start on page 17 of this publication. Along with lithologic description, several diagnostic foraminifera and echinoids aid distinction of Suwannee Limestone from Ocala Limestone. Furthermore, there are some microfossil assemblage similarities between the Suwannee Limestone and the Avon Park Formation which help to distinguish them from the Ocala Limestone. Both of the former contain Fallotella spp. which is found infrequently at the base of the Ocala Limestone (personal communication, Jonathan Bryan). These units contain Discorinopsis gunteri which is not found in the Ocala Limestone. The occurrence of Nummulites spp. and Lepidocyclina spp. in the Ocala Limestone helps to distinguish it from the Suwannee Limestone and the Avon Park Formation in the study area.

Where sediments of the undifferentiated Hawthorn Group occur, their presence is hypothesized by the authors to have effectively capped and hindered dissolution of the underlying limestones. As such, where the Miocene undifferentiated Hawthorn Group sediments are present, the Upper Oligocene Tampa Member of the Arcadia Formation (Hawthorn Group), Lower Oligocene Suwannee Limestone and/or Upper Eocene Ocala Limestone often reside at a higher elevation relative to surrounding areas without Hawthorn Group sediments. An excellent example of this can be seen in cross-section A-A' (OFMS 104; Plate 2, W-15933).

Much of the Tarpon Springs quadrangle is located within the Hillsborough and Withlacoochee River Basins, as well as the Crystal River to St. Petersburg Basin (Figure 3). A small portion of the Alafia River Basin occurs in the southeastern-most corner of the study area (Hydrologic Unit Codes Basins, 1993). There are numerous springs and spring-fed rivers in these basins within the study area, including nine springs in Hernando County, fourteen springs in 


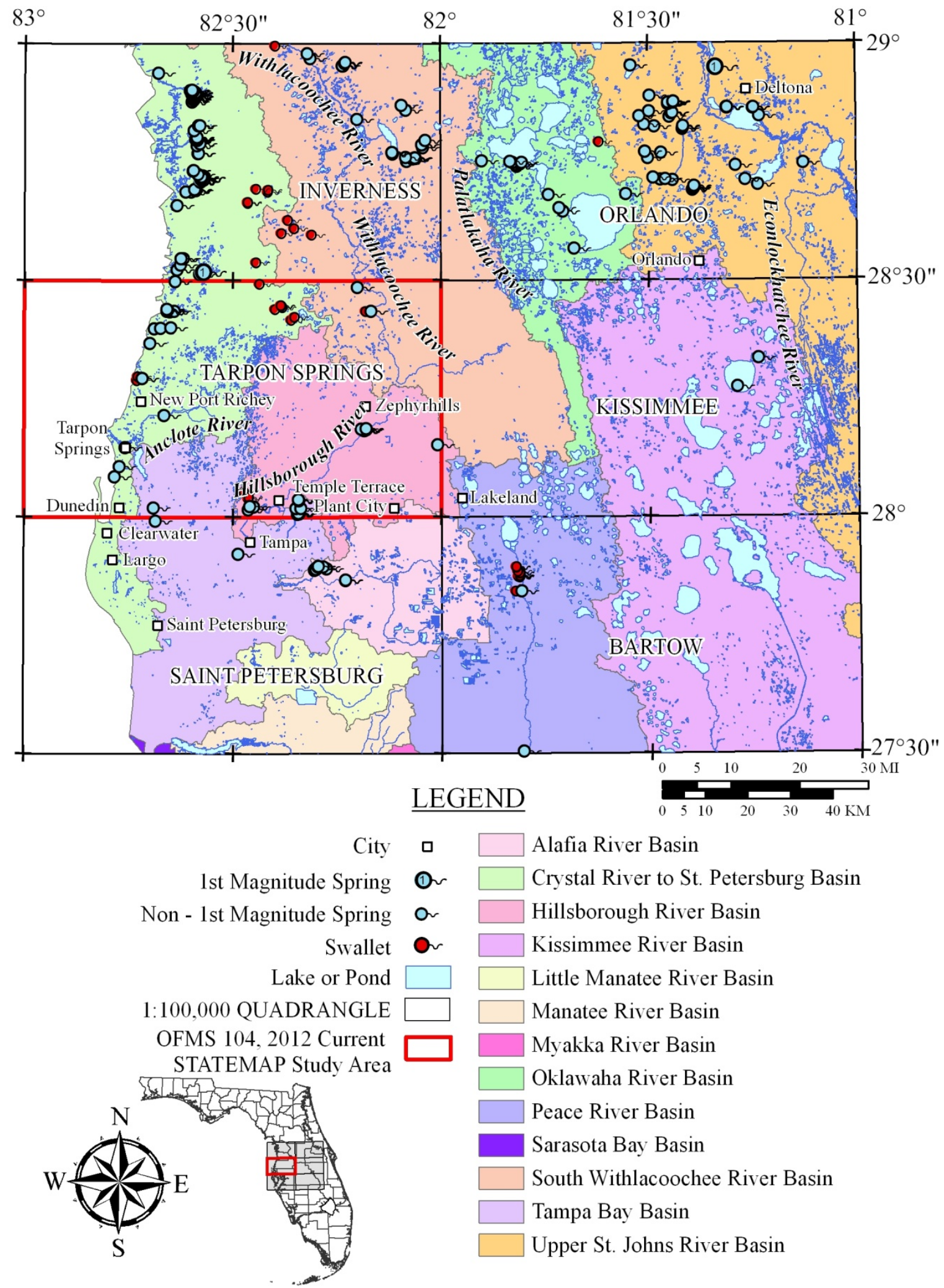

Figure 3. Location of selected river basins, springs, swallets and other water bodies. 


\section{FLORIDA GEOLOGICAL SURVEY}

Hillsborough County, fourteen springs in Pasco County, four in Pinellas County and one in Polk County. These include fourteen second magnitude springs and twenty-seven lesser magnitude springs (Scott et al., 2004). A second magnitude spring is defined as having a minimum average flow between 10 and 100 cubic feet per second, (6.46 or 64.6 million gallons per day; Copeland, 2003). These feed several of the more dominant rivers in the area including the Anclote, Hillsborough and Withlacoochee Rivers. Portions of the recharge areas for many of the mentioned springs and the numerous smaller springs in Hernando, Hillsborough, Pasco, Pinellas, and Polk Counties are located within the study area. Many of these springs have shown significant increases in pollutants in the last few decades, particularly nitrate (Phelps, 1994; Phelps, 2004; Jones et al., 1996; Scott et al., 2002; Upchurch et al., 2004; Copeland et al., 2009). Detailed geologic mapping of lithostratigraphic units in this area provides critical data needed for future assessments of the vulnerability of the aquifer systems and springs to contamination. Understanding the surficial geology of the map area is a key factor in developing management and protection plans, not only for the springs, but for the unconfined portions of the Floridan aquifer system.

Karst processes have extensively modified the topography of the region, and continue to actively shape it today. Karst topography is characterized by solutional features, subterranean drainage, and caves, all of which occur within the study area (Poucher and Copeland, 2006). Downward infiltration of slightly acidic rain and surface water through preferential pathways, such as joints, fractures, and bedding planes, combined with groundwater fluctuations, cause dissolution of the carbonate rocks (Waltham et al., 2005).

The most common karst landforms observed in the study area are sinkholes. Three types of sinkholes dominate the region: 1) solution-subsidence, 2) cover-subsidence, and 3) covercollapse. Solution-subsidence sinkholes occur where overburden is relatively thin. Downward infiltrating rain and surface water, combined with fluctuations in groundwater, infiltrates into joints, fractures, and bedding planes slowly dissolving the carbonate rocks below generally forming a large, broad, shallow low-angle surface depression (Tihansky, 1999). Coversubsidence sinkholes occur where overburden is relatively thick. The overburden sediments, primarily low cohesion sediments, ravel into joints and fractures down into cavities below via infiltrating rain and surface water dissolving carbonate rock, resulting in a relatively small, gently sloped surface depression (Waltham et al., 2005). Cover-collapse sinkholes occur where the overburden sediments contain some amount of cohesive sediments, such as clay, that acts mechanically as a bridge overlying a cavity within the carbonate rocks below (Waltham et al., 2005). The overburden sediments abruptly collapse into the cavity when either the weight of the overburden sediments exceeds the bridging sediment's load-bearing capacity, or when the potentiometric surface of groundwater within the carbonate rocks drops below bridging sediments, no longer providing the necessary buoyancy to help support those bridging sediments (Waltham et al., 2005; Beck and Sinclair, 1986).

The variability of the karst observed within the study area is closely related to the thickness of overburden and the presence/absence of Hawthorn Group clays within the overburden mantling the region's carbonate rocks. Those clays are often the sediments that create a bridge over any cavities which have formed within the carbonates. The study area can be divided into two main karst regions: the areas upon the Brooksville Ridge and the areas surrounding it.

On the Brooksville Ridge, where overburden sediments are significantly thicker than the surrounding areas, Hawthorn Group clays are more prevalent (although often not laterally 
continuous). The Brooksville Ridge exhibits an undulatory and pocked topography due to variable karstification dependent upon the presence and thickness of the Hawthorn Group clays. When present, the clays protect the underlying carbonate rocks as a confining barrier against infiltrating acidic surface water, reducing the effects of karstification. Where not present or where only semi-confining clay sediments exist, the acidic surface water actively dissolves the underlying carbonates. Both cover-collapse and cover-subsidence types of sinkholes occur on the Brooksville Ridge; however, cover-collapse sinkholes are more frequent on the ridge due to the bridging capacity of the Hawthorn Group clays.

On the flanks of the Brooksville Ridge, karstification becomes more prevalent as Hawthorn Group clays thin and pinch-out. As surface water or groundwater flows off and towards the Brooksville Ridge's leading edges it encounters both less clayey and thinner clay sediments leading to contact with the carbonate rocks of the Suwannee Limestone and the Tampa Member of the Arcadia Formation (Hawthorn Group) resulting in increased karstification.

Generally the overburden sediments are thickest and contain a higher percentage of clay and clayey sediments resulting more frequently in the occurrence of cover-collapse sinkholes to the west and south of the Brooksville Ridge. To the east of the Brooksville Ridge, extending towards the Green Swamp, the overburden sediments are less thick (see OFMS 104, Plate 3) resulting in both cover-subsidence and cover-collapse sinkholes (Sinclair and Stewart, 1985). Several wells examined in this study located on the flanks of the Brooksville Ridge exhibited the effects of that increased karstification. The samples for those wells typically exhibited increased amounts of sand, organics and clayey sand interspersed with occasional bits of carbonate rock at depth followed by a correspondingly deeper than expected top of first carbonate rock unit. In the southeastern reaches of the study area, where the Peace River Formation is present and contains occasional and sufficiently shallow carbonate rocks, cover-collapse sinkholes occur.

Anthropogenic activities combined with extreme weather and climatic conditions can lead to accelerated karstification. The study area has experienced two such events in recent years. In January 2010, freezing or near freezing conditions were experienced for a record 11 consecutive days within the Plant City/Dover area, which is famous for its strawberry crops. In order to protect their crops, farmers spray them with groundwater to create a protective rind of ice which insulates the crop from freezing temperatures (SWFWMD, 2010). During freezing conditions, farmers are allowed to pump additional amounts of groundwater beyond their normal permitted daily rate of consumption. During average seasonal weather conditions, farmers in the Plant City/Dover area are permitted to pump approximately 38 million gallons per day (MGD) (SWFWMD, 2010). During freezing conditions, farmers in the Plant City/Dover area are permitted to pump up to approximately 942 MGD, a 2,479\% increase in pumping above normal rates (SWFWMD, 2010). Pumping at that increased rate caused the FAS to drop as much as 60 feet in and around the Plant City/Dover area (SWFWMD, 2010). As a result of that extreme drop, over 750 local wells went dry, and more than 150 sinkholes formed within the vicinity (SWFWMD, 2010).

In June 2012, Tropical Storm Debby dropped record amounts of rain on the state of Florida and caused significant flooding within the study area (National Oceanic and Atmospheric Administration, 2012). In 2011, leading up to that storm event, Florida was experiencing drought conditions (SWFWMD, 2012) during which regional groundwater levels had been lowered considerably due to groundwater pumping. With such lowered regional groundwater levels, much of the region's overburden sediments no longer had the necessary buoyancy support from below. As such, when Tropical Storm Debby dropped its rain on the area, the additional weight 
from the rain water in the overburden sediments, and lubrication of sediments, caused the formation of numerous sinkholes around the state and within the study area.

\section{Structure}

Several structural features have affected the geology of the region (Figure 4). The Peninsular Arch, a structurally high area which affected deposition from the Cretaceous to the early Cenozoic, is the dominant subsurface feature of the Florida peninsula (Applin and Applin, 1944; Applin, 1951; Puri and Vernon, 1964; Williams et al., 1977; Schmidt, 1984; Miller, 1986; Scott, 1997). The axis of the Peninsular Arch, which lies to the east of the study area, extends from southeastern Georgia to the vicinity of Lake Okeechobee in southern Florida in a general northwest to southeast trend. The crest of the arch passes beneath Alachua County and is highest in Union and Baker Counties north of the study area. The arch was a topographic high during most of the Cretaceous Period and had Upper Cretaceous sediments deposited upon it (Applin, 1951). It formed a relatively stable base for Eocene carbonate deposition (Williams et al., 1977). The arch did not affect mid-Tertiary to Holocene sediment deposition (Williams et al., 1977; Scott, 1997).

The Ocala Platform is the most prominent structure affecting the near surface depositional and post-depositional environments within the map area. Hopkins (1920) originally named this feature the Ocala Uplift. Vernon (1951) described the Ocala Uplift as a gentle flexure developed in Tertiary sediments with a northwest-southeast trending crest. Because there is continuing uncertainty about the origin of this feature, Scott (1988) used the term Ocala Platform, rather than Ocala Uplift or Ocala Arch, since it does not have a structural connotation.

The Ocala Platform, which underlies the current study area, influenced late Tertiary sediment deposition. Miocene sediments of the Hawthorn Group are thought to have been deposited across the platform (Scott, 1981a; Scott, 1988; Scott, 1991a). Post-Miocene erosion has removed sediments of the Hawthorn Group from much of the crest of the Ocala Platform, exposing Eocene and Oligocene carbonates (Cooke, 1945; Espenshade and Spencer, 1963; Scott, 1981b). This is evident throughout the eastern and western portions of the map area (OFMS 104; Plate 1). Undifferentiated sediments, thickest on the flanks of the Brooksville Ridge, have subsequently been deposited on the exposed Eocene and Oligocene carbonates. These consist of residual clays, sands, and aeolian sands deposited during the Miocene to Holocene (Scott, 1997).

\section{Geomorphology}

Healy (1975) recognized eight possible marine terraces within the study area (Figure 5) based upon elevations above mean sea level (MSL): the Silver Bluff terrace at elevations between 1 and 10 feet ( 0.3 and 3 meters), the Pamlico terrace at elevations between 10 and 25 feet ( 3 and 7.6 meters), the Talbot terrace at elevations between 25 and 42 feet (7.6 and 12.8 meters) above mean sea level (MSL), the Penholoway terrace at elevations between 42 and 70 feet (12.8 and 21.3 meters) above MSL, the Wicomico terrace at elevations between 70 to 100 feet (21.3 to 30.5 meters) above MSL, the Sunderland/Okefenokee terrace at elevations between 100 and 170 feet (30.5 and 51.8 meters) above MSL, the Coharie terrace at elevations between 170 and 215 feet (51.8 and 65.5 meters), and the Hazlehurst terrace (Coastwise Delta Plain) at elevations between 215 and 320 feet (65.5 and 97.5 meters). Detailed discussions and correlations of 
these marine terraces and relict shorelines have been attempted by many authors, including Matson and Sanford (1913), Cooke (1931, 1939), Flint (1940, 1971), MacNeil (1950), Alt and Brooks (1965), Pirkle et al. (1970), Healy (1975), and Colquhoun et al. (1991).

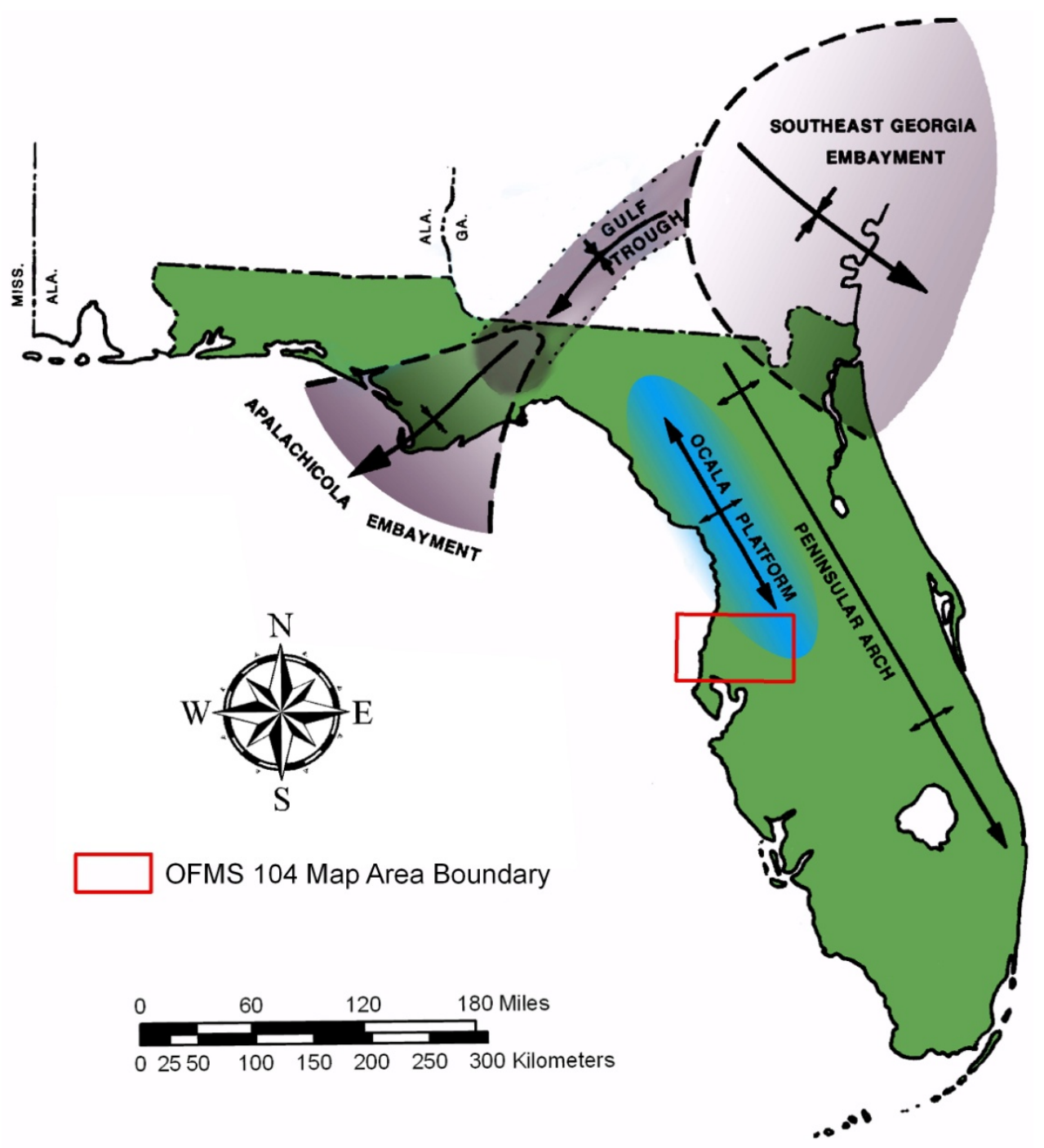

Figure 4. Principal subsurface structures of north Florida (modified from Puri and Vernon, 1964 and Schmidt, 1984).

White (1970) inferred by its elevation that the Brooksville Ridge must be related to the Wicomico with sea level over 100 feet (30.5 meters) above MSL. However, White (1970) also noted that the Brooksville Ridge has "suffered so much differential subsidence from solution of underlying limestone that it is difficult to correlate." Isostatic rebound initiated by carbonate dissolution further complicates tracing elevationally-delineated features in Florida (Opdyke et al., 1984; Adams et al., 2010).

According to Scott et al., (in preparation), the study area falls within three geomorphic districts: the Central Lakes District, the Ocala Karst District and the Sarasota River District 
(OFMS 104; Plate 3, Figure 2). These districts are further subdivided into terranes by Scott et al., (in preparation). The only terrane within the Central Lakes District to occur within the mapped area is the Lake Wales Ridge Complex. The terranes present within the Ocala Karst District in the mapped area are the Brooksville Ridge, Green Swamp, Land O' Lakes Karst Plain, and Williston Karst Plain. All three terranes within the Sarasota River District (the Coastal Lowlands, Pinellas Ridge and the Polk-DeSoto Plain) are present in the study area (OFMS 104; Plate 3, Figure 3).

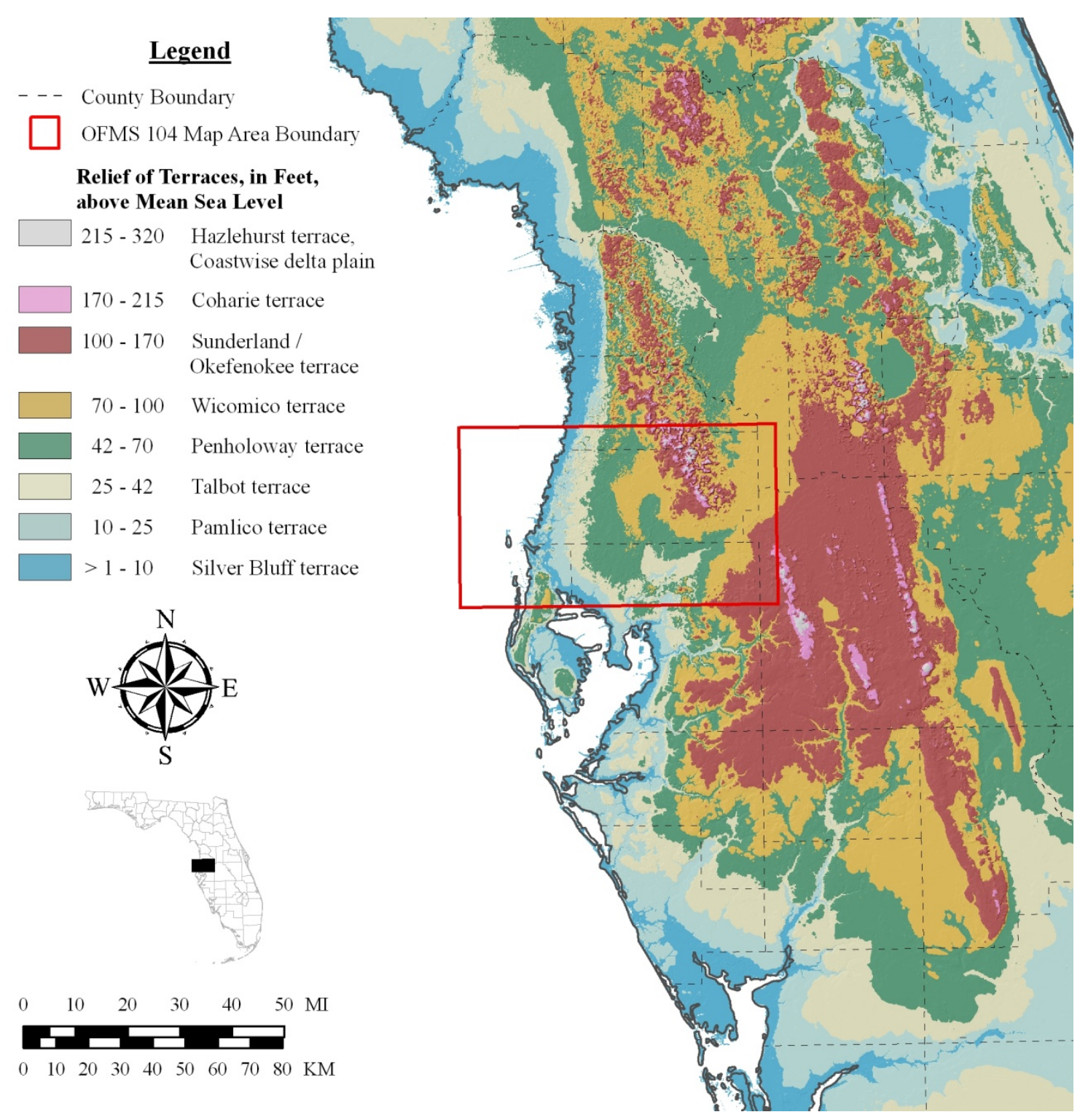

Figure 5. Terraces in Florida (after Healy, 1975).

\section{Central Lakes District}

The Central Lakes District occupies most of the Central Highlands of Cooke (1939) in peninsular Florida. The district extends from eastern Alachua County, southeastern Bradford 
County and southern Clay County to southernmost Highlands County (OFMS 104; Plate 3, Figure 2). The Central Lakes District lies east and south of the Ocala Karst District, south of the Okefenokee Basin District, west of the Barrier Island Sequence District, east of the Sarasota River District, and north of the Everglades District. A thick sequence (up to 200 feet [61 meters]) of siliciclastic and carbonate sediments of the Upper Oligocene-Lower Pliocene Hawthorn Group and siliciclastic sediments of the Pliocene-Pleistocene Cypresshead Formation and undifferentiated sediments overlie the Upper Eocene Ocala Limestone in the district. Dissolution of the limestone and subsequent subsidence or collapse has created the characteristic rolling hills, sinkhole lakes and dry sinks that dominate the landscape. Portions of the district are internally drained due to the presence of karst features and the permeable sand cover. Elevations vary from approximately 50 feet (15.2 meters) above MSL to more than 300 feet (91.4 meters) above MSL. The Central Lakes District, Lake Wales Ridge Complex occurs in the southeastern portion of the study area.

\section{Lake Wales Ridge Complex}

The Lake Wales Ridge Complex is an area of higher elevation rising above the Green Swamp to the north and west and the Polk-DeSoto Plain to the south and southwest (OFMS 104, Plate 3, Figures 1 and 3). The ridge area is the remnant of a broader upland that has been eroded and lowered by sea level fluctuations, fluvial erosion and aeolian redistribution of sediments. Elevations generally range from 20 feet (6.1 meters) to 310 feet (94.5 meters) above MSL. Where this terrane occurs along the eastern part of the study area, elevations range from 110 feet (33.5 meters) to 230 feet (70.1 meters) above MSL. The area is predominantly well drained. Drainage is primarily internal through the numerous karst features present.

The Lower Oligocene Suwannee Limestone underlies the Lake Wales Ridge Complex within the study area (Arthur et al., 2008). The Oligocene-Pliocene Hawthorn Group, consisting of phosphatic sand, clay and carbonate, overlies the Suwannee Limestone. Sand and clayey sand of the Pliocene-Pleistocene Cypresshead Formation overlie the Hawthorn Group (Scott et al., 2001). In some areas, aeolian sand dunes are present.

\section{Ocala Karst District}

The Ocala Karst District encompasses a broad area from Wakulla County in the panhandle to Hillsborough and Pinellas Counties in west-central peninsular Florida (OFMS 104, Plate 3, Figure 2). Carbonate sediments ranging from the Middle Eocene Avon Park Formation to the Upper Oligocene-Lower Miocene Tampa Member of the Arcadia Formation, Hawthorn Group lie near the land surface. Dissolution of these carbonates has created distinct landforms that characterize the district, including caves, caverns, numerous springs, sinking streams (swallets) and resurgent streams. The Ocala Karst District is covered by a siliciclastic sedimentary cover of varying thickness ranging from a few feet (1 meter) to as much as 200 feet (61 meters). The Ocala Karst District merges with the Central Lakes District with which it shares a karstic influence. The southern terminus of the district occurs where impermeable Hawthorn Group sediments retard the development of karst features in the Sarasota River District and streams and rivers become more common.

Elevations within the district, and in the study area, range from sea level along the Gulf of Mexico coast to in excess of 300 feet (91.4 meters) above MSL on the Brooksville Ridge. The topography over much of the district is gently rolling with only minor relief. However, on the 
Brooksville Ridge, the topography looks more like that of the Central Lakes District and relief may exceed 200 feet (61 meters).

Carbonate sediments of the Upper Eocene Ocala Limestone and Lower Oligocene Suwannee Limestone lie at or near the land surface in this district within the study area. There also exist Miocene undifferentiated Hawthorn Group, undifferentiated Tertiary/Quaternary sediments, and Quaternary Beach Ridge and Dune, the latter particularly associated with or along the western flank of the Brooksville Ridge. The Ocala Karst District is dominated by sinkholes and shallow bowl-shaped depressions, producing rolling topography. Generally, a variably permeable siliciclastic cover allows downward percolating groundwater to gradually dissolve the underlying limestone, leading to cover collapse sinkholes and cover subsidence features (Sinclair and Stewart, 1985). Cover collapse sinkholes form rather abruptly from the structural failure of an underlying cavern roof. An excellent example of this is at Devil's Millhopper Geological State Park, located in Alachua County north of the present study area (Evans et al., 2004). Cover subsidence features generally occur in areas where sediments sag as carbonates dissolve underneath. Typically, areas such as these have shallow sinks formed by the downward raveling of the siliciclastic overburden filling voids created by gradual dissolution of underlying carbonates or by dissolution of the carbonate surface. Rock collapse sinks occur but are uncommon.

Regional geomorphic terranes are recognized within the Ocala Karst District based on elevation, abundance of karst features, drainage, and relief. In the study area, these include the Brooksville Ridge, Green Swamp, the Land O’ Lakes Karst Plain, and the Williston Karst Plain (OFMS 104, Plate 3, Figures 1 and 3).

\section{Brooksville Ridge}

The Brooksville Ridge, described by White (1970) as "the most massive of the ridges which rise above the general level of the Central Upland" stands out in stark contrast to the surrounding karst plains. It is subdivided into two sections, northern and southern, separated by the Withlacoochee River. The northern Brooksville Ridge begins in Gilchrist and Alachua Counties and terminates in Levy and Marion Counties. The southern section extends from Citrus County southward into Pasco County. The two sections of the ridge differ in elevation, length to width ratio and underlying geology. The topography of the Brooksville Ridge varies significantly ranging from nearly sea level in local sink holes to over 300 feet (91.4 meters) above MSL. The southern portion of the Brooksville Ridge occurs within the study area (OFMS 104, Plate 3, Figures 1 and 3). This portion of the ridge ranges in elevation from approximately 65 feet (19.8 meters) to more than 300 feet (91.4 meters) above MSL.

The topography of the southern Brooksville Ridge displays significant variability. The southern portion of the ridge becomes progressively hillier and the terrain relief increases from north to south. White (1970) describes the southern ridge area as having "the most irregular surface to be found in any area of comparable size in peninsular Florida." From the vicinity of Brooksville southward the hills are higher and more closely spaced. North of Brooksville the hills are more widely spaced and generally lower elevations, an indication of more mature karst.

The southern Brooksville Ridge is more complex geologically than the northern section. The northern section of the southern Brooksville Ridge, from near the Citrus-Hernando County line northward, is underlain by Upper Eocene Ocala Limestone with variable thicknesses of weathered Miocene undifferentiated Hawthorn Group sediments and Tertiary/Quaternary undifferentiated siliciclastics. Within the study area, the Lower Oligocene Suwannee Limestone occurs more 
commonly as the uppermost carbonate unit with overlying weathered Hawthorn Group and less frequent Tertiary/Quaternary undifferentiated siliciclastics. Sand dunes are common on the flanks of the southern part of the Brooksville Ridge.

\section{Green Swamp}

The Green Swamp occurs in parts of Hernando, Pasco, Sumter, Lake, Polk and Hillsborough Counties. It is bounded on the north by the Williston Karst Plain, on the west by the Brooksville Ridge and Land O' Lakes Karst Plain, on the south by the Polk-DeSoto Plain and on the south and east by the Lake Wales Ridge Complex (OFMS 104, Plate 3, Figures 1 and 3). The entire area is very poorly drained and swamp conditions prevail due to the high potentiometric surface of the Floridan aquifer system. Elevations within the swamp range from 40 feet (12.2 meters) to 200 feet (61 meters) above MSL. A few areas of sand dunes are found in the swamp. Karst features are common throughout the Green Swamp but there are few springs.

The Green Swamp occurs in the eastern part of the study area where elevations range from 40 feet (12.2 meters) to 150 feet (45.7 meters) above MSL. It is primarily underlain by the Upper Eocene Ocala Limestone with the Lower Oligocene Suwannee Limestone under the southwestern part of the area. Miocene undifferentiated Hawthorn Group sediments occur scattered throughout the swamp. Undifferentiated Tertiary/Quaternary siliciclastic sediments cover much of the Green Swamp. Within the study area, Green Swamp is underlain by either Ocala Limestone or Suwannee Limestone and Quaternary undifferentiated sediments.

\section{Land O’ Lakes Karst Plain}

The Land O' Lakes Karst Plain occurs from southern Hernando County southward to Pinellas and Hillsborough Counties (OFMS 104, Plate 3, Figures 1 and 3). It lies west of the southern end of the Brooksville Ridge, west of the Green Swamp and north and west of the PolkDeSoto Plain, Coastal Lowlands and the Pinellas Ridge. Elevations of the karst plain within the study area range from sea level to 140 feet (42.7 meters) above MSL. The occurrence of karst features varies from abundant and closely spaced to scattered. Sand dunes are present in several areas of the karst plain. This area varies from poorly drained to well drained and there are many springs.

The northern half of the Land O’ Lakes Karst Plain is underlain by the Lower Oligocene Suwannee Limestone (where present) or the Upper Eocene Ocala Limestone. The Upper Oligocene to Lower Miocene Tampa Member of the Arcadia Formation, Hawthorn Group underlies the southern portion of the karst plain. An overburden of clays and sands of the Miocene undifferentiated Hawthorn Group, undifferentiated Quaternary siliciclastic sediments and Quaternary Beach Ridge and Dune covers much of the karst plain.

\section{Williston Karst Plain}

The Williston Karst Plain extends from western Alachua County southward into southern Sumter County. It is bounded on the west by the Brooksville Ridge, on the east by the Hawthorne Lakes Region, the Fairfield Karst Hills, the Ocala Karst Hills, the Tavares Lakes Region and the Lake Wales Ridge Complex, and the Green Swamp to the south (OFMS 104, Plate 3, Figures 1 and 3). Elevations in the terrane range from 8 feet (2.4 meters) to 162 feet (49.4 meters) above MSL. A 
small section of the Williston Karst Plain occurs within the northern portion of the study area with elevations that range from 50 feet (15.2 meters) to 110 feet (33.5 meters) above MSL.

Much of the Williston Karst Plain is well drained. However, the southern portion becomes more poorly drained toward Tsala Apopka Lake and the Green Swamp. A number of springs occur within the karst plain. Within the study area, the Williston Karst Plain is underlain by the Upper Eocene Ocala Limestone. Undifferentiated Tertiary/Quaternary siliciclastic sediment covers the karst plain and small dune fields are common in the area.

\section{Sarasota River District}

The Sarasota River District covers much of west-central peninsular Florida extending from Hillsborough and Pinellas Counties southward to the Caloosahatchee River in Lee and Glades Counties. The Sarasota River District lies south of the Ocala Karst District, west of the Central Lakes District and north of the Everglades District (OFMS 104, Plate 3, Figure 2).

Impermeable siliciclastic sediments of the Upper Oligocene-Lower Pliocene Hawthorn Group underlie the Sarasota River District allowing for the development of the numerous rivers and streams. The district is characterized by this occurrence of these rivers and streams which are more common than in any other geomorphic district in Florida. The rivers in the Sarasota River District include the Alafia, Peace, Manatee, Braden, and Myakka Rivers and their tributaries. The Ocala Karst District merges with the Sarasota River District where the Hawthorn Group sediments retard the development of karst features. The Sarasota River District to the Central Lakes District transition occurs where the impermeable sediments of the Hawthorn Group either become more permeable due to a facies change or where the Hawthorn Group sediments are eroded and no longer retard the development of karst features. The separation of the Sarasota River District from the Everglades District occurs where the surface-water flow pattern shifts to a southerly, broad flow pattern.

The landscape of the Sarasota River District is relatively flat with limited relief. Elevations range from sea level along the Gulf of Mexico to more than 185 feet (56.4 meters) above MSL along the boundary with the Central Lakes District. The Sarasota River District includes the Coastal Lowlands, Pinellas Ridge and the Polk-DeSoto Plain. The Polk-DeSoto Plain occurs in a limited area along the southeastern edge of the study area.

\section{Coastal Lowlands}

The Coastal Lowlands terrane forms the western portion of the Sarasota River District adjacent to the Gulf of Mexico (OFMS 104, Plate 3, Figures 1 and 3). It nearly surrounds the Pinellas Ridge in Pinellas County. It occurs in the region west and south of the Polk-DeSoto Plain. Elevations in the Coastal Lowlands vary from sea level to 77 feet (23.5 meters) above MSL. The coastal areas have had greater impacts due to erosion from more recent Pleistocene sea levels than the relative highland areas to the east in the Polk-DeSoto Plain. The greatest variability in elevations in the Coastal Lowlands is in the river valleys which drain to the west and south in the Sarasota River District. Most of the terrane is underlain by Upper Oligocene-Lower Pliocene Hawthorn Group units and Pliocene-Pleistocene shelly sediments.

Within the study area, elevations in the Coastal Lowlands range from sea level to 50 feet (15.2 meters) above MSL. Changes in elevation are not extreme due to the location of this terrane in the study area being limited to the northern end of Old Tampa Bay and the coastal areas west of the 
Pinellas Ridge. The geologic units underlying the terrane in this area are the Upper OligoceneLower Miocene Tampa Member of the Arcadia Formation (Hawthorn Group) and undifferentiated Quaternary sediments as well as Holocene sands of the barrier islands on the Gulf of Mexico coastline.

\section{Pinellas Ridge}

The Pinellas Ridge occurs on the northern Pinellas peninsula in Pinellas County (OFMS 104, Plate 3, Figures 1 and 3). It is bounded on the north by the Land O' Lakes Karst Plain and on the west, south and east by the Coastal Lowlands which broaden toward the south and east. The Pinellas Ridge consists of Miocene undifferentiated Hawthorn Group and undifferentiated Quaternary sediments that remain as a relative highland in Pinellas County.

The northern one-quarter of the ridge occurs within the map area. Elevations within the terrane and the study area range from sea level to 105 feet (32 meters) above MSL. The ridge is well drained. The portion of the Pinellas Ridge occurring in the map area is karstic. There are numerous sinkholes apparent on topographic maps, LiDAR and aerial photographs.

\section{Polk-DeSoto Plain}

The Polk-DeSoto Plain occurs west of the Lake Wales Ridge Complex, south of the Green Swamp, southeast of the Land O' Lakes Karst Plain, and east of the Coastal Lowlands (OFMS 104, Plate 3, Figures 1 and 3). Elevations range from 5 feet (1.5 meters) to 185 feet (56.4 meters) above MSL. The terrain is relatively flat with the greatest relief occurring along numerous stream and river valleys that are incised into the underlying Upper Oligocene-Lower Pliocene Hawthorn Group and undifferentiated Quaternary silicilastic sediments. Very few karst features are recognized on the Polk-DeSoto Plain.

The Polk-DeSoto Plain only occurs in the southeastern most portion of the study area where the elevation ranges from 30 feet (9.1 meters) to 170 feet (51.8 meters) above MSL. The Lower Oligocene Suwannee Limestone underlies the Polk-DeSoto Plain within the study area (Arthur et al., 2008). The Hawthorn Group, consisting of phosphatic sand, clay and carbonate, overlies the Suwannee Limestone. Sand and clayey sand of the weathered Hawthorn Group and undifferentiated Quaternary silicilastic sediments overlie the Hawthorn Group (Scott et al., 2001).

\section{LITHOSTRATIGRAPHIC UNITS}

\section{Tertiary System}

\section{Eocene Series}

\section{Avon Park Formation}

The Middle Eocene Avon Park Formation (Tap), first described by Applin and Applin (1944), is exposed in limited areas just north of the study area in Citrus and Levy Counties (Scott et al., 2001; Green et al., 2010; Williams et al., 2012). The unit, which is entirely a subsurface unit within the USGS Tarpon Springs 30 x 60 minute quadrangle, was encountered in many of the wells utilized for this study and efforts were made to include it in the geologic cross sections where suitable well coverages existed (see OFMS 104, Plate 2) 


\section{FLORIDA GEOLOGICAL SURVEY}

Lithology of the Avon Park Formation can vary between limestone and dolostone. The limestones consist of cream to light brown to tan, poorly to well-indurated, variably fossiliferous grainstone and wackestone, with rare mudstone. The limestones are often interbedded with tan to brown, very poorly to well-indurated, very fine to medium crystalline, fossiliferous (molds and casts), vuggy dolostones. Minor clay beds and organic-rich laminations may occur, especially at or near the top of the unit. Although not common, sedimentary structures include cross-beds and burrows. The burrows (Callianassa sp.) generally occur in the uppermost thinly bedded up-dip part of the formation (e.g., where the unit crops out in Citrus and Levy Counties; Green et al., 2010 and Williams et al., 2012). Accessory minerals include chert, pyrite, celestine, gypsum and quartz (some as doubly-terminated euhedral crystals "floating" in vugs).

Fossils present in the unit include mollusks, foraminifera (Spirolina sp., Lituonella floridana, Bolivina spp., and Cushmania [Dictyoconus] americana), echinoids (Neolaganum [Peronella] dalli), algae and carbonized plant remains. Porosity in the Avon Park Formation is generally intergranular in the limestone section. Fracture porosity occurs in the more densely recrystallized dolostone and intercrystalline porosity is characteristic of sucrosic textures. Pinpoint vugs and fossil molds are present to a lesser extent.

Distinction between the Middle Eocene Avon Park Formation and the unconformably overlying unit, the Upper Eocene Ocala Limestone, can at times be difficult in the study area. Dolomitization of the Avon Park Formation and common recrystallization of the lowermost Ocala Limestone has significantly altered the original rock lithology and fabric. Fossil indicators are only somewhat helpful because the latest deposits of the Avon Park Formation and the earliest deposits of the Ocala Limestone are both bank assemblages, consistent with deposition in a shallow-water limestone bank or plateau, not unlike the present day Bahama Banks (Bryan, 2004). Karst development on the surface of the Avon Park Formation and later the Ocala Limestone, in addition to regional erosion over the Ocala Platform, has left an undulatory contact that does not allow clear definition of regional outcrops based upon elevation. A modern analog is evident along the Waccasassa Bay and Withlacoochee Bay shorelines where modern islands of Ocala Limestone with elevations rarely more than 5 feet (1.5 meters) above MSL exist in shallow flats where water depths are typically less than 3 feet ( 0.9 meters) (see Green et al., 2010; Plate 3, Photos 1 and 3).

The top of the Avon Park ranges from approximately 100 feet (30.5 meters) below MSL in W-19229 (OFMS 104; Plate 2, cross-section A-A') to approximately 540 feet (164.6 meters) below MSL in W-4506 (OFMS 104; Plate 2, cross-sections D-D'). Due to graphical space constraints, as well as limited coverage of deeper wells, the total thickness of the Avon Park Formation was not investigated in this study.

The Avon Park Formation forms part of the FAS (Southeastern Geological Society Ad Hoc Committee on Florida Hydrostratigraphic Unit Definition, 1986).

\section{Ocala Limestone}

The Upper Eocene Ocala Limestone (To), first described by Dall and Harris (1892), is a biogenic marine limestone comprised largely of foraminifera, mollusks, echinoids and bryozoans. The Ocala Limestone, which sits unconformably on the Avon Park Formation, is recrystallized to varying degrees, particularly within the northern part of the study area.

Based on lithologic differences, the Ocala Limestone can be informally subdivided into an upper and lower unit (Scott, 1991b). This subdivision, while often apparent in cores and 
quarries, is not readily apparent in cuttings. As a consequence of this, the geologic crosssections do not break out the upper and lower Ocala Limestone. The upper unit is typically a white to cream, fine- to coarse-grained, poorly to well-indurated, moderately to well-sorted, very fossiliferous limestone (wackestone, packstone, and grainstone). Fossils commonly include foraminifera (Lepidocyclina ocalana), bryozoans, mollusks, and a rich diversity of echinoids. The lower unit is typically a white to cream, fine- to medium-grained, poorly to moderately indurated, moderately to well-sorted limestone (grainstone to packstone). Fossils include foraminifera (Amphistegina pinarensis, Nummulites [Camerina] vanderstoki, Nummulites [Operculinoides] ocalana), bryozoans, algae, mollusks, echinoids, and crustaceans.

The Ocala Limestone occurs throughout the study area and is near the surface along the northeastern portion of the map area (OFMS 104, Plate 1). The top of the Ocala Limestone ranges from 80 feet (24.4 meters) above MSL in W-19364, (OFMS 104; Plate 2, cross-section B$\mathrm{B}^{\prime}$ ) to 425 feet (129.5 meters) below MSL in W-4506 (OFMS 104; Plate 2, cross-section D-D'). Approximately 75 percent of the wells utilized for geologic cross-sections penetrate the entire thickness of the Ocala Limestone. In these wells, the thickness of the Ocala Limestone ranges from 205 feet (62.5 meters) in W-12459 (OFMS 104; Plate 2, cross-section C-C') to 60 feet (18.3 meters) in W-8840 (OFMS 104; Plate 2, cross-section F-F').

The Ocala Limestone is generally thickest in the southern and western portions of the study area off the nose of the Ocala Platform. It approaches 200 feet (61 meters) in these areas (Arthur et al., 2008). The Ocala Limestone forms part of the FAS (Southeastern Geological Society Ad Hoc Committee on Florida Hydrostratigraphic Unit Definition, 1986).

\section{Oligocene Series}

\section{Suwannee Limestone}

The Lower Oligocene Suwannee Limestone (Ts), named by Cooke and Mansfield (1936), consists of limestone (grainstone and packstone) in the study area. The unit is typically gray, tan, light brown to moderate brown, moderately to very well-indurated, finely to coarsely crystalline, with limited occurrences of fossiliferous beds. Chert is present in the unit, particularly in the northwestern portion of the study area. Porosity types include intergranular and moldic. Sedimentary features include bioturbation and cross-bedding (Budd, 2002). Fossils present in the unit include mollusks, corals, echinoids (including the index fossil Rhyncholampas gouldii), as well as abundant miliolids, and other benthic foraminifera such as Discorinopsis gunteri, Fallotella [Dictyoconus] cookei and Fallotella [Coskinolina] floridana.

The Suwannee Limestone unconformably overlies the Ocala Limestone throughout much of the study area and is unconformably overlain by undifferentiated Hawthorn Group sediments, Tampa Member of the Arcadia Formation (Hawthorn Group), undifferentiated Quaternary sediments or Quaternary Beach Ridge and Dune sediments. Isolated outcrops and residual chert boulders of Suwannee Limestone may be seen in the northeastern portion of the map area (OFMS 104, Plate 1).

According to Arthur et al., (2008), the Suwannee Limestone may be conformably overlain by the Tampa Member of the Arcadia Formation (Hawthorn Group) in parts of Hillsborough and Pinellas Counties. In these areas, the two units may be difficult to differentiate due to the presence of trace amounts (typically less than three percent) of fine quartz sand in the upper Suwannee Limestone and Tampa Member, leading to geologists familiar with the region using the term "SuwTampaHaw" (Tom Scott, personal communication, 2004). In these 
instances, the formation break was based on the presence of phosphate and general increase in quartz sand size in the Tampa Member.

In the field area, the Suwannee Limestone is often highly karstified. In the subsurface, the Suwannee Limestone and Ocala Limestone can be exceedingly difficult to distinguish in the study area because both units may be dominated by packstones and often contain no diagnostic fossils. Brewster-Wingard et al. (1997) in their study of these units further south in the Florida peninsula state: “...the delineation of the formational boundary [between the Ocala Limestone and the Suwannee Limestone] is often difficult, and foraminifera frequently provide the most reliable means for identifying the units.” The present authors agree with this opinion for the present study area.

Outcrops of Suwannee Limestone are most common in the northwestern portion of the study area near the Gulf of Mexico, in the vicinity of Port Richey and Aripeka. The Suwannee Limestone also crops out east and south of the Brooksville Ridge (OFMS 104, Plate 1). The top of the Suwannee Limestone ranges from approximately 95 feet (29 meters) above MSL in W19364 (OFMS 104; Plate 2, cross-section B-B') to 160 feet (48.8 meters) below MSL in W-4506 (OFMS 104; Plate 2, cross-sections C-C' and D-D'). Generally, the thickness of the Suwannee Limestone increases to the southwest of the study area with a maximum thickness of 310 feet (94.5 meters) in W-14004 (OFMS 104; Plate 2, cross-section C-C'). The Suwannee Limestone is absent in the northeastern portion of the map area, (OFMS 104; Plate 2, cross-section A-A'), most likely as a result of dissolution and karst processes.

The Suwannee Limestone, where present, forms part of the FAS (Southeastern Geological Society Ad Hoc Committee on Florida Hydrostratigraphic Unit Definition, 1986).

\section{Oligocene-Pliocene Series}

\section{Hawthorn Group}

Sediments of the Upper Oligocene to Pliocene Hawthorn Group are thought to have been deposited over the Ocala Platform throughout the study area, but post-Pliocene erosion and karstification have removed sediments from the crest of the Ocala Platform, exposing the Eocene and Oligocene carbonates in portions of the map area (Cooke, 1945; Espenshade and Spencer, 1963; Scott, 1981b). Hawthorn Group sediments within the study area consist of phosphatic siliciclastics (sands, silts and clay) and carbonates. Fossils in the Hawthorn Group are sparse but may include vertebrate remains, corals, and mollusks. Benthic foraminifera characteristic of the Hawthorn Group include Archaias spp. and Sorites sp. Williams et al. (1977) report that the most commonly found fossils are oysters and coral heads.

Within the mapped area, the Hawthorn Group is composed of the Tampa Member of the Arcadia Formation, the Peace River Formation and undifferentiated Hawthorn Group (Th) sediments, all of which lie unconformably over the Suwannee Limestone (see discussion above for more information regarding the contact with the Suwannee Limestone). The various Hawthorn Group sediments are unconformably overlain by the Cypresshead Formation, undifferentiated Tertiary/Quaternary sediments, undifferentiated Quaternary sediments, and Quaternary Beach Ridge and Dune sediments. 
Arcadia Formation

The Upper Oligocene (Brewster-Wingard et al., 1997) to Middle Miocene Arcadia Formation (Tha) is comprised of a yellowish gray to white, variably sandy (quartz and phosphorite) carbonate intercalated with beds of siliciclastic-dominant sediments. Although limestone is present, dolostones are most common, ranging in grain size from microcrystalline to medium, with the more coarse material being sucrosic. Minor clays and chert beds (some comprised of silicified clay) also occur (Upchurch et al., 1982; Scott, 1988). Porosity types include intergranular and moldic. Within the study area, the Arcadia Formation is comprised entirely of the Tampa Member. South of the Tarpon Springs quadrangle, the Tampa Member grades conformably into undifferentiated Arcadia Formation (Arthur et al., 2008).

\section{Tampa Member}

The Upper Oligocene to Lower Miocene (Brewster-Wingard et al., 1997) Tampa Member of the Arcadia Formation (That) varies from white to yellowish gray in color and ranges from a wackestone to packstone with varying amounts of quartz sand, silt and clay (Scott, 1988). Phosphate (typically less than 3 to 5 percent), dolomite, chert, siliceous limestone and silicified corals are also present (Upchurch et al., 1982). Fossil molds of foraminifera, mollusks, gastropods and algae are all common within the Tampa Member (Scott, 1988). Pinkish gray to light olive gray dolostones also occur with a similar fossil assemblage and accessory mineral assemblage as the limestones. Thin sand and clay beds can be found intermittently within the unit (Scott, 1988). Porosity of the unit is generally intergranular and moldic.

The top of the Tampa Member ranges from approximately 150 feet (45.7 meters) above MSL in parts of the Brooksville Ridge where it has been protected from dissolution by overlying sediments of the Undifferentiated Hawthorn Group (OFMS 104; Plate 2, cross-section A-A', W15933) to approximately 30 feet (9.1 meters) below MSL in the southwest part of the study area (OFMS 104; Plate 2, cross-sections C-C' and D-D', W-4506). The maximum observed thickness of the Tampa Member is 135 feet (41.1 meters) in W-4506 (OFMS 104; Plate 2, cross-section C$\left.\mathrm{C}^{\prime}\right)$.

In the study area, the Tampa Member overlies the Suwannee Limestone and the contact appears to be locally conformable. In many wells, the transition between the Tampa Member and the underlying undifferentiated Arcadia Formation is gradational, with phosphorite content generally increasing with depth. In parts of Pasco and northern Hillsborough Counties, the unit is unconformably overlain by undifferentiated clay-rich Hawthorn Group sediments and Undifferentiated Quaternary sediments. In the southeastern portion of the study area, the Tampa Member is unconformably overlain by the Peace River Formation. Further towards the east and south, the Tampa Member facies grades laterally into the Arcadia Formation (Arthur et al., 2008).

Along the updip erosional pinchout of the Tampa Member, where it forms an irregular subcrop contact with the Suwannee Limestone, the top of the FAS generally coincides with the uppermost carbonate unit occurrence (Arthur et al., 2008). 


\section{FLORIDA GEOLOGICAL SURVEY}

\section{Peace River Formation}

The Middle Miocene to Lower Pliocene (Scott, 1988; Covington, 1993) Peace River Formation (Thp) is comprised of yellowish gray to olive gray, interbedded sands, clays and carbonates with the siliciclastic component being dominant (Scott, 1988). Phosphate sand and gravel are most common in the uppermost beds, although they are generally interspersed throughout the unit. The Peace River Formation contains a diverse fossil assemblage of marine and terrestrial fauna (e.g., shark teeth, ray spines, horse teeth, vertebrae, dugong and whale ribs), particularly within the Bone Valley Member. Porosity types in the formation are generally intergranular, except in the carbonate-rich zones, where moldic porosity is also present.

The Peace River Formation unconformably overlies the underlying Arcadia Formation. South and east of the study area, the Bone Valley Member of the Peace River Formation directly overlies the Tampa Member (Arthur et al. 2008). There are some wells which have thin (less than 15 feet [4.6 meters]) beds of phosphate-rich sediment which may equate to Bone Valley Member in the very southeastern corner of the map area. However, these beds could not be clearly determined to be part of the Bone Valley Member. Therefore, they are considered by the authors to be undifferentiated Peace River Formation sediments.

South of the study area, the contact between the Peace River Formation and Arcadia Formation can be problematic in some localities. In many cores, the two units appear to be conformable, with phosphate-rich siliciclastics grading with depth into more siliciclasticinterbedded carbonates containing generally finer-grained and less abundant phosphorite (Arthur et al., 2008). In such cases, the lower contact of the Peace River Formation is estimated based on sedimentary structures as well as a best approximation of where the overall lithologic sequence becomes more carbonate dominant (Scott, 1988). In the southeastern portion of the study area, the contact is readily recognized at the first occurrence of quartz-sandy mudstones and increased phosphorite at the top of the Tampa Member.

Maximum elevations of the Peace River Formation occur in the southeastern portion of the study area in the vicinity of Plant City, where the unit exceeds 120 feet (36.6 meters) above MSL (OFMS 104; Plate 2, Cross Section C-C'). The maximum observed depth of the Peace River Formation is just above sea level in W-15321 (OFMS 104; Plate 2, Cross-section C-C'). Thicknesses range to 90 feet (27.4 meters) in W-15342 (OFMS 104; Plate 2, Cross-section C-C'). The Peace River Formation is within the upper portion of the Intermediate Aquifer System/Confining Unit (IAS/ICU) and regionally is a confining to semi-confining lithostratigraphic unit. The Peace River Formation and undifferentiated Hawthorn Group sediments comprise a low-permeability confining to semi-confining facies within the IAS/ICU within the study area. (Southeastern Geological Society Ad Hoc Committee on Florida Hydrostratigraphic Unit Definition, 1986).

Hawthorn Group (Undifferentiated)

Undifferentiated Hawthorn Group sediments lie unconformably above Oligocene carbonates in parts of Hernando, Hillsborough, Pasco and Pinellas Counties. Throughout the north-central portion of the map area, undifferentiated Hawthorn Group sediments occur along the Brooksville Ridge as well as within karst features and isolated lenses flanking the ridge. Vernon (1951) describes “Miocene Hawthorn formation” sediments along the Brooksville Ridge 
in Citrus County as greenish-gray montmorillonitic clays. The distribution of these sediments, as well as the occurrence of hard-rock phosphate in the region, lend support to the proposal by Scott (1988) and Upchurch (1992) that Hawthorn Group sediments were much more aerially extensive in the region prior to removal by erosion, weathering, and karstification.

The undifferentiated Hawthorn Group (Th) sediments are light olive gray and blue gray in unweathered sections and reddish brown to reddish gray in weathered sections. They consist of poorly- to moderately-consolidated, clayey sands to silty clays and relatively pure clays with little to no phosphate due to leaching and transport (Scott, 2001). They are typically deeply weathered. In parts of the Brooksville Ridge north of the present study area, undifferentiated Hawthorn Group sediments are often overlain by more than 20 feet (6.1 meters) of undifferentiated Tertiary/Quaternary sediments and/or Quaternary sediments. Hard-rock phosphate deposits are associated with the undifferentiated Hawthorn Group sediments in several places along the eastern flank of the Brooksville Ridge (Green et al., 2011; Williams et al., 2011). These hard-rock phosphate deposits were formed by dissolution of phosphate from the Hawthorn Group and subsequent precipitation in karst features within the Ocala Limestone (Scott, 2001).

Where present, undifferentiated Hawthorn Group sediments unconformably overlie the Ocala Limestone, the Suwannee Limestone, or the Tampa Member of the Arcadia Formation (Scott et al., 2001). They are at times unconformably overlain by undifferentiated Quaternary sediments or undifferentiated Tertiary/Quaternary sediments. In Pinellas County, undifferentiated Hawthorn Group sediments are overlain unconformably by undifferentiated Quaternary sediments (OFMS 104, Plate 1).

Due to the karstic nature of the Brooksville Ridge, elevations of the undifferentiated Hawthorn Group sediments are highly variable. Within the study area, the top of the unit may exceed 300 feet (91.4 meters) above MSL. Along the flanks of the ridge, thin beds of the undifferentiated Hawthorn Group were penetrated in various wells (OFMS 104, Plate 2). In these, the top of the Hawthorn Group ranges from 301 feet (91.7 meters) above MSL in W15933 (OFMS 104; Plate 2, cross-section A-A') to near MSL in several wells (OFMS 104; Plate 2). The undifferentiated Hawthorn Group ranges from 150 feet to 15 feet (45.7 to 4.6 meters) thick in wells in the study area, some thickness of which includes deeply weathered sections.

Undifferentiated Hawthorn Group sediments are often clayey sands with some permeability, and only rarely consist of relatively pure clays. The undifferentiated Hawthorn Group sediments generally have low permeability and form part of the IAS/ICU (Southeastern Geological Society Ad Hoc Committee on Florida Hydrostratigraphic Unit Definition, 1986).

\section{Tertiary/Quaternary Systems}

\section{Pliocene/Pleistocene Series}

\section{Cypresshead Formation}

The Pliocene-Pleistocene Cypresshead Formation (Tc) is a mottled reddish-brown to reddish-orange to white, unconsolidated to poorly consolidated, fine to very coarse grained, variably clayey to clean quartz sand. Cross-bedded sands are common within this formation. Discoid quartzite pebbles, mica, and ghosts of nearshore marine mollusks are often present. Cypresshead Formation sediments are present only in a small area along the southeastern edge of the Tarpon Springs quadrangle. Elevations range from approximately 130 feet (39.6 meters) to 
over 220 feet (67 meters) above MSL in the mapped area. These sediments sit unconformably on the Peace River Formation. Permeable sediments of the Cypresshead Formation form part of the surficial aquifer system (SAS) (Southeastern Geological Society Ad Hoc Committee on Florida Hydrostratigraphic Unit Definition, 1986).

\section{Undifferentiated Tertiary/Quaternary Sediments}

Undifferentiated Tertiary/Quaternary sediments (TQu) are siliciclastics that are separated from the lithologically similar undifferentiated Quaternary sediments primarily on the basis of elevation (Scott et al., 2001). Pleistocene sea levels reached a maximum of approximately 100 feet (30.5 meters) above MSL (Colquhoun, 1969; Colquhoun et al., 1991). The sediments which occur above 100 feet (30.5 meters) MSL are predominantly older than Pleistocene but may have been reworked during the Pleistocene. They may contain sediments reworked from the Hawthorn Group and/or Cypresshead Formation during Pleistocene and late Pliocene fluctuations in sea level. In some areas these sediments may become difficult to differentiate from weathered Hawthorn Groups sediments.

They are present in the southeastern portion of the map area where they overlie the Peace River Formation (OFMS 104; Plate 1) in areas where elevations exceed 100 feet (30.5 meters). These poorly-consolidated to unconsolidated siliciclastics are white to gray to orange to bluegreen, fine- to coarse-grained, clean to clayey unfossiliferous sands, sandy clays and clays with variable admixtures of clay and organics. Permeable sediments of the undifferentiated Tertiary/Quaternary sediments form part of the SAS (Southeastern Geological Society Ad Hoc Committee on Florida Hydrostratigraphic Unit Definition, 1986).

\section{Pleistocene to Holocene Series}

\section{Undifferentiated Quaternary Sediments}

Undifferentiated Quaternary sediments (Qu) in the study area lie unconformably on the Suwannee Limestone, Tampa Member of the Arcadia Formation, or undifferentiated Hawthorn Group sediments (OFMS 104, Plate 1). The Suwannee Limestone and the undifferentiated Quaternary sediments are only in direct contact in some instances where the Tampa Member is absent from the section. The undifferentiated Quaternary sediments present west of the Brooksville Ridge in the mapped area may be highly variable in thickness.

Generally, these undifferentiated Quaternary sediments consist of white to gray to orange to blue-green, fine- to coarse-grained, clean to clayey unfossiliferous sands, sandy clays and clays with variable admixtures of organics. They are separated from the undifferentiated Tertiary/Quaternary sediments primarily due to current elevations below 100 feet (30.5 meters). The undifferentiated Quaternary sediments form part of the SAS (Southeastern Geological Society Ad Hoc Committee on Florida Hydrostratigraphic Unit Definition, 1986). Where these sediments lack clays and overlie the Oligocene limestones, they are hydraulically connected to the Floridan aquifer system. 


\section{Quaternary Beach Ridge and Dune}

The sediments of the beach ridge and dune (Qbd) are a subdivision of the undifferentiated Quaternary sediments that are noted on the basis of surficial expression of relict beach ridges and dunes. These sediments typically unconformably overlie the Ocala Limestone, Suwannee Limestone or the Tampa Member of the Arcadia Formation. Beach ridge and dune sediments occur in the western part of the study area along the eastern and western flanks of the southern Brooksville Ridge (OFMS 104; Plate 1). Subdivisions of the undifferentiated Quaternary sediments are not formally recognized lithostratigraphic units, but are noted to facilitate a better understanding of Florida’s Quaternary geology (Scott, 2001).

Beach ridge and dune sediments are dominantly siliciclastic sands and are unconsolidated to poorly consolidated. Organics typically occur as disseminated organic matrix, roots and plant debris, carbonized remains or charcoal. These sediments are considered part of the SAS (Southeastern Geological Society Ad Hoc Committee on Florida Hydrostratigraphic Unit Definition, 1986).

\section{Holocene Sediments}

Sediments mapped as Holocene (Qh) may include quartz sands, marls, organics, and minor carbonate sands and mud. They may also include fresh-water gastropods. Within the study area, these occur near the present coastline in barrier islands on the Gulf of Mexico. Studies by Davis et al. (1992) suggest Holocene age for these barrier islands.

\section{HYDROGEOLOGY}

Hydrostratigraphic units within the map area, in ascending order, consist of the FAS, the IAS/ICU, and the SAS (Southeastern Geological Society Ad Hoc Committee on Florida Hydrostratigraphic Unit Definition, 1986). The FAS, the primary source for springs and drinking water in the region, is generally comprised of carbonate units of the Avon Park Formation, the Ocala Limestone, and the Suwannee Limestone. The sands, silts, clays and carbonates of the Hawthorn Group comprise the IAS/ICU. The IAS/ICU is highly localized and laterally discontinuous in the study area. The SAS is comprised of the undifferentiated Tertiary/Quaternary sediments (TQu), the undifferentiated Quaternary sediments (Qu) and the Beach Ridge and Dune sediments (Qbd).

Where clayey siliciclastic sediments of the Hawthorn Group and younger units are thick and continuous, they provide confinement for the FAS, but where the clayey siliciclastic sediments of the Hawthorn Group and younger units are thin, missing or lack significant clay component, karst features often occur. Swallets (stream-to-sink features) are of particular concern to geoscientists and hydrogeologists. Several of these are found in the southern Brookville Ridge, particularly where areas of undifferentiated Hawthorn Group sediments thinly cover the Suwannee Limestone or Tampa Member of the Arcadia Formation. 


\section{DERIVATIVE PRODUCTS}

Several derivative products will come from this project. During the mapping project, data from over 800 wells with samples were analyzed, and data for over 500 wells total were used (Appendix A includes those within the study area boundary and top of limestone rock information from Water Management District wells). Formation picks, made on all available wells with cores and cuttings samples, allow creation of a structure contour map of the top of the FAS, along with the construction of structure contour and isopach maps of the IAS/ICU in the area. Additional derivative data anticipated to come from this mapping effort include aquifer vulnerability assessment maps. Data derived from prior STATEMAP products have often been used to augment other Florida Geological Survey and Florida Aquifer Vulnerability Assessment (FAVA) projects in the state (Arthur et al., 2007; Baker et al., 2007). 


\section{OPEN-FILE REPORT 98}

\section{REFERENCES}

Adams, P.N., Opdyke, N.D., and Jaeger, J.M., 2010, Isostatic uplift driven by karstification and sea-level oscillation: Modeling landscape evolution in North Florida: Geology, v. 38, p. 531534.

Alt, D., and Brooks, H.K., 1965, Age of the Florida marine terraces: Journal of Geology, v. 73, p. 406-411.

Applin, P., 1951, Possible future petroleum provinces of North America - Florida: American Association of Petroleum Geologists Bulletin, v. 35, p. 405-407.

Applin, P.L., and Applin, E.R., 1944, Regional subsurface stratigraphy and structure of Florida and southern Georgia: American Association of Petroleum Geologists Bulletin, v. 28, p. 1673-1753.

Arthur, J.D., 1993, Geologic Map of Pasco County, Florida: Florida Geological Survey OpenFile Map Series 42, Scale: 1:126,720.

Arthur, J.D., and Campbell, K. M., 1993, Geologic Map of Pinellas County, Florida: Florida Geological Survey Open-File Map Series 43, Scale: 1:126,720.

Arthur, J.D., Wood, H.A.R., Baker, A.E., Cichon, J.R., and Raines, G.L., 2007, Development and implementation of a Bayesian-based aquifer vulnerability assessment in Florida: Natural Resources Research, v. 16, p. 93-107.

Arthur, J.D., Fischler, C., Kromhout, C., Clayton, J.M., Kelley, G.M., Lee, R.A., Li, L., O’Sullivan, M., Green, R.C., and Werner, C.L., 2008, Hydrogeologic framework of the Southwest Florida Water Management District: Florida Geological Survey Bulletin 68, 102 p., 59 plates.

Baker, A.E., Wood, H.A.R., and Cichon, J.R., 2007, The Marion County Aquifer Vulnerability Assessment: unpublished report submitted to Marion County Board of County Commissioners in fulfillment of Marion County Project No. SS06-01, March 2007, 42 p.

Beck, B.F., and Sinclair, W.C., 1986, Sinkholes in Florida: An introduction: University of Central Florida, Orlando, Florida Sinkhole Research Institute Report 85-86-4, 24 p.

Brewster-Wingard, G.L., Scott, T.M., Edwards, L.E., Weedman, S.D., and Simmons, K.R., 1997, Reinterpretation of the peninsular Florida Oligocene: an integrated stratigraphic approach: Sedimentary Geology, v. 108, p. 207-228.

Bryan, J.R., 2004, Larger foraminifera: Introduction, biology, ecology, taxonomic and stratigraphic listings and comments on Florida fossil assemblages: Gainesville, Florida Paleontological Society, Florida Fossil Invertebrates, Part 6, 28 p. 


\section{FLORIDA GEOLOGICAL SURVEY}

Budd, D.A., 2002, The relative roles of compaction and early cementation in the destruction of permeability in carbonate grainstones: A case study from the Paleogene of west-central Florida, USA: Journal of Sedimentary Research, v. 72, p. 116-128.

Campbell, K.M., 1993a, Geologic map of Hernando County, Florida: Florida Geological Survey Open-File Map Series 35, Scale 1:126,720.

, 1993b, Geologic map of Polk County, Florida: Florida Geological Survey Open-File Map Series 46, Scale 1:126,720.

, 1993c, Geologic map of Sumter County, Florida: Florida Geological Survey Open-File Map Series 40, Scale 1:126,720.

Campbell, K.M., and J. Arthur, 1993, Geologic Map of Hillsborough County, Florida: Florida Geological Survey Open-File Map Series 45, Scale: 1:126,720.

Colquhoun, D.J., 1969, Coastal plain terraces in the Carolinas and Georgia, U.S.A., in Wright, H.E., Jr., ed., Quaternary Geology and Climate: Volume 16 of the Proceedings of the VII Congress of the International Association for Quaternary Research, p. 150-162.

Colquhoun, D.J., Johnson, G.H., Peebles, P.C., Huddlestun, P.F., and Scott, T., 1991, Quaternary geology of the Atlantic Coastal Plain, in Morrison, R.B., ed., Quaternary nonglacial geology; Conterminous U.S.: Boulder, Geological Society of America, The Geology of North America, v. K-2, p. 629-650.

Cooke, C.W., 1931, Seven coastal terraces in the southeastern United States: Washington Academy of Sciences Journal, v. 21, p. 503-513.

, 1939, Scenery of Florida interpreted by a geologist: Florida Geological Survey Bulletin 17, 120 p.

, 1945, Geology of Florida: Florida Geological Survey Bulletin 29, 342 p.

Cooke, C.W., and Mansfield, W.C., 1936, Suwannee limestone of Florida (abstract): Geological Society of America Proceedings 1935, p. 71-72.

Copeland, R., 2003, Florida spring classification system and spring glossary: Florida Geological Survey Special Publication 52, 17 p.

Copeland, R., Doran, N.A., White, A.J., and Upchurch, S.B., 2009, Regional and statewide trends in Florida's spring and well groundwater quality (1991-2003): Florida Geological Survey Bulletin 69, 203 p.

Covington, J.M., 1993, Neogene nannofossils of Florida, in Zullo, V.A., Harris, W.B., Scott, T.M., and Portell, R.W., eds., The Neogene of Florida and adjacent regions: Florida Geological Survey Special Publication 37, 112 p. 
Dall, W.H., and Harris, G.D., 1892, Correlation papers, Neocene: U.S. Geological Survey Bulletin 84, 349 p.

Davis, R.A., Jr., Hine, A.C., and Shinn, E.A., 1992, Holocene coastal development on the Florida peninsula, in Fletcher, C.H., III and Wehnmiller, J.F., eds., Quaternary Coasts of the United States: Marine and Lacustrine Systems, SEPM Special Publication 48, p. 193-212.

Espenshade, G.H., and Spencer, C.W., 1963, Geologic features of phosphate deposits of northern peninsular Florida: United States Geological Survey Bulletin 1118, 115 p.

Evans, W.L., III, Green, R.C., Bryan, J.R., and Paul, D.T., 2004, Geologic map of the western portion of the USGS 1:100,000 scale Gainesville quadrangle, northern Florida: Florida Geological Survey Open-File Map Series 93, scale 1:100,000, 2 plates.

Flint, R.F., 1940, Pleistocene features of the Atlantic coastal plain: American Journal of Science, v. 238, p. 757-787. , 1971, Glacial and Quaternary Geology: New York, John Wiley and Sons, Inc., 892 p.

Green, R.C., Williams, C.P., Flor, A.D., Paul, D.T., Kromhout, C., and Scott, T.M., 2010, Geologic map of the western portion of the USGS Ocala 30 x 60 minute quadrangle, northcentral Florida: Florida Geological Survey Open-File Map Series 101, scale 1:100,000, 3 plates.

Green, R.C., Williams, C.P. Burdette, K.E., Bassett, S.W., Flor, A.D., and Paul, D.T., 2011, Geologic map of the eastern portion of the USGS Inverness 30 x 60 minute quadrangle, central Florida: Florida Geological Survey Open-File Map Series 102, scale 1:100,000, 3 plates.

Healy, H.G., 1975, Terraces and shorelines of Florida: Florida Geological Survey Map Series 71, scale: 1:2,095,200.

Hopkins, O.B., 1920, Drilling for oil in Florida: U.S. Geological Survey Press Bulletin, April, 1920.

Hydrologic Unit Codes: Basins, 1993: Tallahassee: Florida Department of Environmental Protection, [vector digital data file].

Jones, G.W., Upchurch, S.B., and Champion, K.M., 1996, Origin of nitrate in groundwater discharging from Rainbow Springs, Marion County, Florida: Brooksville, Southwest Florida Water Management District Report, 155 p.

MacNeil, F.S., 1950, Pleistocene shorelines in Florida and Georgia: U.S. Geological Survey Professional Paper 221-F, p. 95-107. 


\section{FLORIDA GEOLOGICAL SURVEY}

Matson, G.C., and Sanford, S., 1913, Geology and groundwater of Florida: U.S. Geological Survey Water Supply Paper 319, 445 p.

Miller, J.A., 1986, Hydrogeologic framework of the Floridan aquifer system in Florida and in parts of Georgia, Alabama, and South Carolina: Regional Aquifer-System Analysis: U.S. Geological Survey Professional Paper 1403-B, 91 p., 33 plates.

National Oceanic and Atmospheric Administration, 2012, Observed Weather Reports: Record Event Report: Tampa/Lakeland: June 26, 2012: National Oceanic and Atmospheric Administration: National Weather Service: National Climatic Data Center: Record Report, http://www.nws.noaa.gov/climate/getclimate.php?wfo=tbw [August, 2012]

Opdyke, N.D., Spangler, D.P., Smith, D.L., Jones, R.C., and Lindquist, R.C., 1984, Origin of the epeirogenic uplift of Pliocene-Pleistocene beach ridges in Florida and development of the Florida karst: Geology, v. 12, p. 226-228.

Phelps, G.G., 1994, Hydrogeology, water quality and potential for contamination of the Upper Floridan Aquifer in the Silver Springs Ground-Water Basin, Central Marion County, Florida: U.S. Geological Survey Water-Resources Investigations Report 92-4159, 69 p.

, 2004, Chemistry of groundwater in the Silver Springs Basin, with an emphasis on Nitrate: U.S. Geological Survey Scientific Investigations Report 2004-5144, 54 p.

Pirkle, E.C., Jr., Yoho, W.H., and Hendry, C.W., Jr., 1970, Ancient sea level stands in Florida: Florida Geological Survey Bulletin 52, 61 p.

Poucher, S., and Copeland, R., 2006, Speleological and karst glossary of Florida and the Caribbean: Gainesville, University Press of Florida, 196 p.

Puri, H.S., and Vernon, R.O., 1964, Summary of the geology of Florida and a guidebook to the classic exposures: Florida Geological Survey Special Publication 5, revised, 312 p.

Schmidt, W., 1984, Neogene stratigraphy and geologic history of the Apalachicola Embayment: Florida Geological Survey Bulletin 58, 146 p.

Scott, T.M., 1981a, The paleo-extent of the Miocene Hawthorn Formation in peninsular Florida [abstract]: Florida Scientist, v. 44, Supplement 1, p. 42.

, 1981b, The Hawthorn Formation of North Florida: Southeastern Geological Society, Field Conference Guidebook, v. 23, p. 15-23.

, 1988, The lithostratigraphy of the Hawthorn Group (Miocene) of Florida: Florida Geological Survey Bulletin 59, 148 p.

, 1991a, Depositional patterns of the Hawthorn Group in Florida: Geological Society of America Abstracts with Programs, v. 23, no. 1, p. 126. 
, 1991b, A geological overview, in Scott, T.M., Lloyd, J.M., and Maddox, G.L., eds., Florida's ground-water quality monitoring program, hydrogeologic framework: Florida Geological Survey Special Publication 32, 97 p.

, 1997, Miocene to Holocene history of Florida, in Randazzo, A.F. and Jones, D.S., eds., The Geology of Florida: Gainesville, University Press of Florida, p. 57-67.

, 2001, Text to accompany the geologic map of Florida: Florida Geological Survey Open-File Report 80, 29 p.

Scott, T.M., Campbell, K.M., Rupert, F.R., Arthur, J.A., Green, R.C., Means, G.H., Missimer, T.M., Lloyd, J.M., and Duncan, J.G., 2001, Geologic map of Florida: Florida Geological Survey Map Series 146, scale 1:750,000.

Scott, T.M., Means, G.H., Means, R.C., and Meegan R.P., 2002, First magnitude springs of Florida: Florida Geological Survey Open-File Report 85, 138 p.

Scott, T.M., Means, G.H., Meegan, R.P., Means, R.C., Upchurch, S.B., Copeland, R.E., Jones, J., Roberts, T., and Willet, A., 2004, Springs of Florida: Florida Geological Survey Bulletin 66, 377 p.

Scott, T.M., Paul, D.T., Means, G.H., and Williams, C.P. (in preparation), Geomorphic map of Florida: Florida Geological Survey, scale 1:750,000.

Sinclair, W.C., and Stewart, J.W., 1985, Sinkhole type, development, and distribution in Florida: Florida Geological Survey Map Series 110, scale 30 miles to 1 inch.

Southeastern Geological Society Ad Hoc Committee on Florida Hydrostratigraphic Unit Definition, 1986, Hydrogeological units of Florida: Florida Geological Survey Special Publication 28, 8 p.

SWFWMD, 2010, Frost-Freeze-FAQs: Southwest Florida Water Management District: http://www.swfwmd.state.fl.us/emergency/frost-freeze/Frost-Freeze-FAQs.pdf [August, 2012)]

SWFWMD, 2012, Rainfall data: Southwest Florida Water Management District: Hydrologic Data: http://www.swfwmd.state.fl.us/data/wmdbweb/rainfall_data_summaries.php [August, 2012].

Tihansky, A.B., 1999, Sinkholes, west-central Florida: U.S. Geological Survey Circular 1182, 20 p.

Upchurch, S.B., Strom, R.N., and Nuckels, M.G., 1982, Silicification of Miocene rocks from central Florida, in Scott, T.M., and Upchurch, S.B., eds., Miocene of the southeastern United States: Florida Geological Survey Special Publication No. 25, p. 251-284 
Upchurch, S.B., 1992, Quality of water in Florida's aquifer systems, in Maddox, G.L., Lloyd, J.M., Scott, T.M., Upchurch, S.B., and Copeland, R., eds., Florida’s groundwater quality monitoring program - Background hydrogeochemistry: Florida Geological Survey Special Publication No. 34, p. 12-51.

Upchurch, S.B., Champion, K.M., Schnieder, J.C., Hornsby, D., Ceryak, R., and Zwanka, W., 2004, Defining springshed boundaries and water-quality domains near first-magnitude springs in north Florida [abstract]: Florida Scientist, v. 67, Supplement 1, p. 52

U.S. Geological Survey, 1978, 1:100,000-scale metric topographic map of Tarpon Springs, Florida: Reston, U.S. Geological Survey, 1 sheet.

Vernon, R.O., 1951, Geology of Citrus and Levy Counties, Florida: Florida Geological Survey Bulletin 33, 256 p.

Waltham, T., Bell, F., and Culshaw, M., 2005, Sinkholes and subsidence, karst and cavernous rocks in engineering and construction: Chichester, Praxis Publishing Ltd., 382 p.

White, W.A., 1970, The geomorphology of the Florida peninsula: Florida Geological Survey Bulletin 51, 164 p.

Williams, C.P., Burdette, K.E., Green, R.C., Bassett, S.W., Flor, A.D., and Paul, D.T., 2011, Text to accompany geologic map of the eastern portion of the USGS Inverness $30 \times 60$ minute quadrangle, central Florida: Florida Geological Survey Open-File Report 96, 40 p.

Williams, C.P., Green, R.C., Bassett, S.W., Hannon, L.M., and Flor, A.D., 2012, Geologic map of the western portion of the USGS Inverness 30 x 60 minute quadrangle, central Florida: Florida Geological Survey Open-File Map Series 103, scale 1:100,000, 3 plates.

Williams, C.P. and Green, R.C., 2012, Text to accompany geologic map of the western portion of the USGS Inverness 30 x 60 minute quadrangle, central Florida: Florida Geological Survey Open-File Report 97, 29 p.

Williams, K.E., Nicol, D., and Randazzo, A.F., 1977, The geology of the western part of Alachua County, Florida: Florida Geological Survey Report of Investigation 85, 97 p.

Yon, J.W., and C.W. Hendry, Jr., 1972, Suwannee Limestone in Hernando and Pasco Counties, Florida: Florida Geological Survey Bulletin 54, Part 1, 42 p. 


\section{ACKNOWLEDGEMENTS}

The authors extend many thanks to the personnel that assisted with access to land holdings: G. Robert and Sharon G. Blanchard for personally showing us their Little Everglades Ranch and allowing access to their property. Donna Watkins with the Florida Department of Environmental Protection's Division of Recreation and Parks expedited the permit process for rock sample collection in Florida State Parks. Florida Park Service staff provided information and staff time to guide the authors to rock outcrops in the state parks that could be collected with the least distraction to visitors. Scott Spalding (Park Manager) allowed access and expedited permitting for new coring in Colt Creek State Park.

Toby Brewer (Weeki Wachee Springs State Park) and Christine Dorrier (Werner-Boyce Salt Springs State Park) were generous with their time and resources in arranging for airboat access to sample outcrops within Werner-Boyce Salt Springs State Park. Dave DeWitt from the Southwest Florida Water Management District (SWFWMD) assisted both with access to private and SWFWMD lands and expedited permitting for new coring. Lonnie Taylor and Brian Nelson from the Southwest Florida Water Management District were very helpful in arranging airboat access to the Hillsborough River. Ross Dickerson and Richard Warren of Hillsborough County Parks and Recreation helped in arranging access to Cone Ranch Audubon Tract.

Bob Cleveland, Ken Campbell, Jesse Hurd, David Paul and Eric Thomas provided field support for drilling operations. Kevin Burdette provided some sample descriptions of wells in addition to the authors. Andy Smith provided geophysical logging for the new cores collected in the study area. Levi Hannon and James Cichon worked to make sure all wells were appropriately located using every piece of archived well location information that could be found. Thank you to Frank Rupert, Jackie Lloyd, Alan Baker and Jon Arthur who reviewed, discussed and edited the product. Tom Scott continues to be an asset to geologic mapping in Florida and the ongoing work to revise the state's geomorphic map. This geologic map was funded in part by the Office of the Florida Geological Survey of the Florida Department of Environmental Protection and by the United States Geological Survey National Cooperative Geologic Mapping Program under assistance award number G11AC20418 in Federal fiscal year 2011. 


\section{APPENDIX A: FGS WELLS UTILIZED FOR STUDY}

This table lists FGS wells within the boundaries of the USGS Tarpon Springs 30 x 60 minute quadrangle utilized for the top of rock model. Due to graphical constraints, not all wells will appear on Plate 1 of OFMS 104. The first 45 wells in the table were utilized for geologic cross-sections and appear on Plates 1 and 2 of OFMS 104.

\begin{tabular}{|c|c|c|c|c|c|c|c|c|}
\hline $\begin{array}{c}\text { Map } \\
\text { ID }\end{array}$ & Well Label & Data Source & Sample Type & Latitude & Longitude & 24K Quad & $\begin{array}{c}\text { Elevation } \\
(\mathrm{ft})\end{array}$ & $\begin{array}{c}\text { Total } \\
\text { Depth }(\mathrm{ft})\end{array}$ \\
\hline 1 & W-662 & FGS & Cuttings & 28.228288 & -82.167886 & ZEPHYRHILLS & 78 & 330 \\
\hline 2 & W-707 & FGS & Cuttings & 28.479229 & -82.450759 & MASARYKTOWN & 67 & 340 \\
\hline 3 & $W-2160$ & FGS & Cuttings & 28.295580 & -82.190209 & DADE CITY & 227 & 957 \\
\hline 4 & W-3428 & FGS & Cuttings & 28.147038 & -82.459560 & LUTZ & 68 & 381 \\
\hline 5 & W-4233 & FGS & Cuttings & 28.220010 & -82.455587 & LUTZ & 74 & 155 \\
\hline 6 & W-4506 & FGS & Cuttings & 28.079499 & -82.658910 & OLDSMAR & 17 & 4298 \\
\hline 7 & W-5069 & FGS & Cuttings & 28.070831 & -82.432781 & SULPHUR SPRINGS & 43 & 1010 \\
\hline 8 & W-5350 & FGS & Cuttings & 28.281960 & -82.116427 & BRANCHBOROUGH & 85 & 200 \\
\hline 9 & W-5486 & FGS & Cuttings & 28.486610 & -82.598278 & PORT RICHEY NE & 36 & 170 \\
\hline 10 & W-5863 & FGS & Cuttings & 28.311297 & -82.290652 & SAN ANTONIO & 106 & 640 \\
\hline 11 & W-6232 & FGS & Cuttings & 28.076783 & -82.623274 & CITRUS PARK & 39 & 1200 \\
\hline 12 & W-6863 & FGS & Cuttings & 28.041039 & -82.001430 & PLANT CITY EAST & 135 & 628 \\
\hline 13 & W-7435 & FGS & Cuttings & 28.463761 & -82.367462 & SPRING LAKE & 94 & 270 \\
\hline 15 & W-8840 & FGS & Cuttings & 28.403423 & -82.197590 & LACOOCHEE & 73 & 250 \\
\hline 16 & W-10354 & FGS & Cuttings & 28.464687 & -82.512562 & PORT RICHEY NE & 67 & 330 \\
\hline 17 & W-10617 & FGS & Cuttings & 28.334840 & -82.200310 & DADE CITY & 124 & 360 \\
\hline 18 & W-10891 & FGS & Cuttings & 28.308975 & -82.674596 & PORT RICHEY & 29 & 647 \\
\hline 19 & W-11287 & FGS & Cuttings & 28.455613 & -82.608865 & PORT RICHEY NE & 36 & 350 \\
\hline 20 & W-11805 & FGS & Cuttings & 28.073403 & -82.521547 & CITRUS PARK & 47 & 506 \\
\hline 21 & W-12345 & FGS & Cuttings & 28.192621 & -82.463833 & LUTZ & 75 & 233 \\
\hline 22 & W-12346 & FGS & Cuttings & 28.284459 & -82.466209 & EHREN & 80 & 250 \\
\hline 23 & W-12367 & FGS & Cuttings & 28.455707 & -82.559396 & PORT RICHEY NE & 46 & 395 \\
\hline 24 & W-12459 & FGS & Cuttings & 28.031394 & -82.097141 & PLANT CITY EAST & 132 & 1200 \\
\hline 25 & W-12831 & FGS & Cuttings & 28.309438 & -82.378337 & EHREN & 70 & 700 \\
\hline 26 & W-13583 & FGS & Cuttings & 28.385552 & -82.669238 & ARIPEKA & 9 & 72 \\
\hline 27 & W-13902 & FGS & Cuttings & 28.369272 & -82.453684 & EHREN & 68 & 700 \\
\hline 28 & W-14004 & FGS & Cuttings & 28.061635 & -82.582973 & CITRUS PARK & 26 & 1174 \\
\hline 29 & W-14221 & FGS & Cuttings & 28.413687 & -82.454740 & MASARYKTOWN & 67 & 707 \\
\hline 32 & W-15321 & FGS & Cuttings & 28.046830 & -82.195589 & PLANT CITY WEST & 87 & 314 \\
\hline 33 & W-15342 & FGS & Cuttings & 28.021549 & -82.059518 & PLANT CITY EAST & 142 & 680 \\
\hline 34 & W-15464 & FGS & Cuttings & 28.151641 & -82.675143 & ELFERS & 24 & 780 \\
\hline 35 & W-15649 & FGS & Cuttings & 28.450092 & -82.653023 & ARIPEKA & 6 & 814 \\
\hline 36 & W-15800 & FGS & Cuttings & 28.000791 & -82.690276 & OLDSMAR & 15 & 340 \\
\hline 37 & W-15933 & FGS & Core & 28.427433 & -82.261633 & SPRING LAKE & 300 & 402 \\
\hline 38 & W-16304 & FGS & Core & 28.471838 & -82.196938 & LACOOCHEE & 63 & 534 \\
\hline 39 & W-17991 & FGS & Core & 28.195559 & -82.167777 & ZEPHYRHILLS & 67 & 559 \\
\hline 40 & W-18020 & FGS & Core & 28.106332 & -82.140822 & PLANT CITY WEST & 95 & 177 \\
\hline 41 & W-18606 & FGS & Both & 28.262230 & -82.682042 & PORT RICHEY & 19 & 145 \\
\hline 42 & W-18895 & FGS & Core & 28.313333 & -82.443333 & EHREN & 77 & 449.5 \\
\hline 43 & W-19229 & FGS & Core & 28.437738 & -82.084744 & CLAY SINK & 80 & 1283 \\
\hline 44 & W-19336 & FGS & Core & 28.307600 & -82.584766 & FIVAY JUNCTION & 52 & 533.5 \\
\hline 45 & W-19364 & FGS & Core & 28.284194 & -82.035444 & BRANKCBOROUGH & 95 & 245.5 \\
\hline 46 & W-131 & FGS & Cuttings & 28.098428 & -82.596526 & CITRUS PARK & 39 & 340 \\
\hline 47 & W-658 & FGS & Cuttings & 28.226715 & -82.168957 & ZEPHYRHILLS & 78 & 325 \\
\hline 48 & W-708 & FGS & Cuttings & 28.480200 & -82.454044 & MASARYKTOWN & 68 & 251 \\
\hline 49 & W-992 & FGS & Cuttings & 28.164810 & -82.775049 & TARPON SPRINGS & 4 & 305 \\
\hline 50 & W-994 & FGS & Cuttings & 28.473769 & -82.547224 & PORT RICHEY NE & 37 & 999 \\
\hline 51 & W-1522 & FGS & Cuttings & 28.142805 & -82.738488 & ELFERS & 22 & 93 \\
\hline 52 & W-1614 & FGS & Cuttings & 28.088174 & -82.745709 & OLDSMAR & 70 & 205 \\
\hline 53 & W-1645 & FGS & Cuttings & 28.040000 & -82.682318 & OLDSMAR & 7 & 140 \\
\hline 54 & W-1646 & FGS & Cuttings & 28.043300 & -82.690505 & OLDSMAR & 5 & 140 \\
\hline 55 & W-1738 & FGS & Cuttings & 28.071302 & -82.764306 & DUNEDIN & 21 & 85 \\
\hline
\end{tabular}


OPEN-FILE REPORT 98

\begin{tabular}{|c|c|c|c|c|c|c|c|c|}
\hline $\begin{array}{l}\text { Map } \\
\text { ID }\end{array}$ & Well Label & Data Source & Sample Type & Latitude & Longitude & 24K Quad & $\begin{array}{c}\text { Elevation } \\
(\mathrm{ft})\end{array}$ & $\begin{array}{c}\text { Total } \\
\text { Depth }(\mathrm{ft})\end{array}$ \\
\hline 56 & W-1739 & FGS & Cuttings & 28.005349 & -82.711838 & OLDSMAR & 57 & 130 \\
\hline 57 & W-1741 & FGS & Cuttings & 28.019081 & -82.772099 & DUNEDIN & 32 & 83 \\
\hline 58 & W-1742 & FGS & Cuttings & 28.077780 & -82.755510 & DUNEDIN & 69 & 147 \\
\hline 59 & W-1743 & FGS & Cuttings & 28.023763 & -82.773398 & DUNEDIN & 24 & 85 \\
\hline 60 & W-1825 & FGS & Cuttings & 28.018409 & -82.113197 & PLANT CITY EAST & 128 & 248 \\
\hline 61 & W-1836 & FGS & Cuttings & 28.250035 & -82.706319 & ELFERS & 32 & 200 \\
\hline 62 & W-1980 & FGS & Cuttings & 28.022628 & -82.739627 & OLDSMAR & 68 & 167 \\
\hline 63 & W-2007 & FGS & Cuttings & 28.006311 & -82.677968 & OLDSMAR & 5 & 1805 \\
\hline 64 & W-2021 & FGS & Cuttings & 28.074840 & -82.296133 & THONOTOSASSA & 48 & 80 \\
\hline 65 & W-2140 & FGS & Cuttings & 28.261466 & -82.677506 & PORT RICHEY & 23 & 206.5 \\
\hline 66 & W-2158 & FGS & Cuttings & 28.062222 & -82.250000 & THONOTOSASSA & 54 & 111 \\
\hline 67 & W-2186 & FGS & Cuttings & 28.018331 & -82.140483 & PLANT CITY WEST & 115 & 87 \\
\hline 68 & W-2199 & FGS & Cuttings & 28.411540 & -82.270981 & SPRING LAKE & 250 & 230 \\
\hline 69 & W-2226 & FGS & Cuttings & 28.485948 & -82.261693 & SPRING LAKE & 71 & 94 \\
\hline 70 & W-2227 & FGS & Cuttings & 28.485944 & -82.261695 & SPRING LAKE & 71 & 176 \\
\hline 71 & W-2353 & FGS & Cuttings & 28.021395 & -82.682318 & OLDSMAR & 0 & 68 \\
\hline 72 & W-2451 & FGS & Cuttings & 28.485925 & -82.261674 & SPRING LAKE & 71 & 208 \\
\hline 73 & W-2469 & FGS & Cuttings & 28.017893 & -82.178843 & PLANT CITY WEST & 98 & 104 \\
\hline 74 & W-2491 & FGS & Cuttings & 28.021872 & -82.090205 & PLANT CITY EAST & 145 & 234 \\
\hline 75 & W-2493 & FGS & Cuttings & 28.032999 & -82.288131 & THONOTOSASSA & 53 & 110 \\
\hline 76 & W-2704 & FGS & Cuttings & 28.000662 & -82.419267 & SULPHUR SPRINGS & 51 & 503 \\
\hline 77 & W-2707 & FGS & Cuttings & 28.373307 & -82.207051 & DADE CITY & 118 & 188 \\
\hline 78 & W-2749 & FGS & Cuttings & 28.039369 & -82.451333 & SULPHUR SPRINGS & 29 & 42 \\
\hline 79 & W-2774 & FGS & Cuttings & 28.116944 & -82.011111 & PLANT CITY EAST & 128 & 198 \\
\hline 80 & W-2778 & FGS & Cuttings & 28.002808 & -82.744379 & OLDSMAR & 72 & 313 \\
\hline 81 & W-2779 & FGS & Cuttings & 28.003431 & -82.745638 & OLDSMAR & 69 & 252 \\
\hline 82 & W-2921 & FGS & Cuttings & 28.073077 & -82.298816 & THONOTOSASSA & 45 & 102 \\
\hline 83 & W-3268 & FGS & Cuttings & 28.037453 & -82.384639 & SULPHUR SPRINGS & 67 & 480 \\
\hline 84 & W-3426 & FGS & Cuttings & 28.007365 & -82.367211 & THONOTOSASSA & 30 & 200 \\
\hline 85 & W-3570 & FGS & Cuttings & 28.281354 & -82.708338 & PORT RICHEY & 18 & 200 \\
\hline 86 & W-3605 & FGS & Cuttings & 28.007813 & -82.285395 & THONOTOSASSA & 94 & 142 \\
\hline 87 & W-3698 & FGS & Cuttings & 28.282304 & -82.709420 & PORT RICHEY & 18 & 100 \\
\hline 88 & W-3714 & FGS & Cuttings & 28.003418 & -82.459527 & SULPHUR SPRINGS & 32 & 208 \\
\hline 89 & W-3742 & FGS & Cuttings & 28.003540 & -82.412570 & SULPHUR SPRINGS & 63 & 306 \\
\hline 90 & W-3805 & FGS & Cuttings & 28.337651 & -82.706318 & PORT RICHEY & 2 & 218 \\
\hline 91 & W-3809 & FGS & Cuttings & 28.147776 & -82.654459 & ELFERS & 31 & 245 \\
\hline 92 & W-3838 & FGS & Cuttings & 28.072502 & -82.010125 & PLANT CITY EAST & 160 & 136 \\
\hline 93 & W-3845 & FGS & Cuttings & 28.004835 & -82.355279 & THONOTOSASSA & 22 & 95 \\
\hline 94 & W-3906 & FGS & Cuttings & 28.001519 & -82.432644 & SULPHUR SPRINGS & 64 & 750 \\
\hline 95 & W-3965 & FGS & Cuttings & 28.377483 & -82.280388 & SPRING LAKE & 228 & 180 \\
\hline 96 & W-3970 & FGS & Cuttings & 28.020833 & -82.380833 & SULPHUR SPRINGS & 41 & 465 \\
\hline 97 & W-3995 & FGS & Cuttings & 28.047779 & -82.097051 & PLANT CITY EAST & 133 & 510 \\
\hline 98 & W-4254 & FGS & Cuttings & 28.126944 & -82.010555 & SOCRUM & 130 & 600 \\
\hline 99 & W-4259 & FGS & Cuttings & 28.029477 & -82.229357 & PLANT CITY WEST & 69 & 345 \\
\hline 100 & $W-4260$ & FGS & Cuttings & 28.029677 & -82.222974 & PLANT CITY WEST & 68 & 750 \\
\hline 101 & W-4261 & FGS & Cuttings & 28.029676 & -82.223244 & PLANT CITY WEST & 68 & 417 \\
\hline 102 & W-4265 & FGS & Cuttings & 28.030377 & -82.223297 & PLANT CITY WEST & 70 & 400 \\
\hline 103 & W-4268 & FGS & Cuttings & 28.030713 & -82.222731 & PLANT CITY WEST & 73 & 800 \\
\hline 104 & W-4269 & FGS & Cuttings & 28.030922 & -82.222662 & PLANT CITY WEST & 73 & 256 \\
\hline 105 & W-4359 & FGS & Cuttings & 28.047876 & -82.424338 & SULPHUR SPRINGS & 44 & 690 \\
\hline 106 & W-4384 & FGS & Cuttings & 28.015665 & -82.767422 & DUNEDIN & 29 & 255 \\
\hline 107 & W-4467 & FGS & Cuttings & 28.002798 & -82.454591 & SULPHUR SPRINGS & 39 & 652 \\
\hline 108 & W-4468 & FGS & Cuttings & 28.344006 & -82.188657 & DADE CITY & 80 & 475 \\
\hline 109 & W-4568 & FGS & Cuttings & 28.018019 & -82.459467 & SULPHUR SPRINGS & 22 & 240 \\
\hline 110 & W-4603 & FGS & Cuttings & 28.054749 & -82.389407 & SULPHUR SPRINGS & 33 & 114 \\
\hline 111 & W-4614 & FGS & Cuttings & 28.045000 & -82.388055 & SULPHUR SPRINGS & 75 & 510 \\
\hline 112 & W-4621 & FGS & Cuttings & 28.012548 & -82.123675 & PLANT CITY EAST & 124 & 650 \\
\hline 113 & W-4645 & FGS & Cuttings & 28.173673 & -82.647176 & ELFERS & 38 & 590 \\
\hline 114 & W-4646 & FGS & Cuttings & 28.033493 & -82.393946 & SULPHUR SPRINGS & 60 & 155 \\
\hline 115 & W-4737 & FGS & Cuttings & 28.038748 & -82.012540 & PLANT CITY EAST & 127 & 310 \\
\hline 116 & W-4747 & FGS & Cuttings & 28.047826 & -82.459359 & SULPHUR SPRINGS & 32 & 129 \\
\hline
\end{tabular}


FLORIDA GEOLOGICAL SURVEY

\begin{tabular}{|c|c|c|c|c|c|c|c|c|}
\hline $\begin{array}{l}\text { Map } \\
\text { ID }\end{array}$ & Well Label & Data Source & Sample Type & Latitude & Longitude & 24K Quad & $\begin{array}{c}\text { Elevation } \\
(\mathrm{ft})\end{array}$ & $\begin{array}{c}\text { Total } \\
\text { Depth }(\mathrm{ft})\end{array}$ \\
\hline 117 & W-4754 & FGS & Cuttings & 28.239027 & -82.165588 & ZEPHYRHILLS & 89 & 306 \\
\hline 118 & W-4886 & FGS & Cuttings & 28.007498 & -82.497749 & SULPHUR SPRINGS & 40 & 415 \\
\hline 119 & W-4918 & FGS & Cuttings & 28.070035 & -82.446468 & SULPHUR SPRINGS & 38 & 280 \\
\hline 120 & W-4956 & FGS & Cuttings & 28.008979 & -82.391104 & SULPHUR SPRINGS & 49 & 306 \\
\hline 121 & W-5011 & FGS & Cuttings & 28.066320 & -82.421242 & SULPHUR SPRINGS & 37 & 350 \\
\hline 122 & W-5054 & FGS & Cuttings & 28.357781 & -82.039811 & BRANCHBOROUGH & 96 & 144 \\
\hline 123 & W-5076 & FGS & Cuttings & 28.011159 & -82.411882 & SULPHUR SPRINGS & 18 & 100 \\
\hline 124 & W-5077 & FGS & Cuttings & 28.014002 & -82.402098 & SULPHUR SPRINGS & 28 & 202 \\
\hline 125 & W-5087 & FGS & Cuttings & 28.052836 & -82.473031 & SULPHUR SPRINGS & 37 & 1265 \\
\hline 126 & W-5101 & FGS & Cuttings & 28.496768 & -82.424348 & MASARYKTOWN & 78 & 358 \\
\hline 127 & W-5124 & FGS & Cuttings & 28.363112 & -82.188480 & DADE CITY & 100 & 115 \\
\hline 128 & W-5271 & FGS & Cuttings & 28.347736 & -82.692938 & PORT RICHEY & 13 & 80 \\
\hline 129 & W-5272 & FGS & Cuttings & 28.217862 & -82.734902 & ELFERS & 21 & 180 \\
\hline 130 & W-5279 & FGS & Cuttings & 28.311369 & -82.693019 & PORT RICHEY & 14 & 95 \\
\hline 131 & W-5282 & FGS & Cuttings & 28.326638 & -82.221987 & DADE CITY & 119 & 153 \\
\hline 132 & W-5284 & FGS & Cuttings & 28.024911 & -82.495798 & SULPHUR SPRINGS & 49 & 156 \\
\hline 133 & W-5339 & FGS & Cuttings & 28.307777 & -82.672431 & PORT RICHEY & 23 & 345 \\
\hline 134 & W-5352 & FGS & Cuttings & 28.225450 & -82.030342 & SOCRUM & 104 & 252 \\
\hline 135 & W-5363 & FGS & Cuttings & 28.003373 & -82.277722 & THONOTOSASSA & 82 & 251 \\
\hline 136 & W-5372 & FGS & Cuttings & 28.061725 & -82.245037 & PLANT CITY WEST & 55 & 140 \\
\hline 137 & W-5423 & FGS & Cuttings & 28.121499 & -82.558684 & CITRUS PARK & 43 & 1195 \\
\hline 138 & W-5448 & FGS & Cuttings & 28.041398 & -82.028015 & PLANT CITY EAST & 125 & 662 \\
\hline 139 & W-5484 & FGS & Cuttings & 28.254741 & -82.702230 & PORT RICHEY & 39 & 225 \\
\hline 140 & W-5485 & FGS & Cuttings & 28.196129 & -82.734731 & ELFERS & 12 & 105 \\
\hline 141 & W-5644 & FGS & Cuttings & 28.120548 & -82.509906 & CITRUS PARK & 56 & 600 \\
\hline 142 & W-5661 & FGS & Cuttings & 28.028437 & -82.634112 & OLDSMAR & 1 & 145 \\
\hline 143 & W-5663 & FGS & Cuttings & 28.047172 & -82.409957 & SULPHUR SPRINGS & 62 & 210 \\
\hline 144 & W-5670 & FGS & Cuttings & 28.051915 & -82.365657 & THONOTOSASSA & 21 & 20 \\
\hline 145 & W-5671 & FGS & Cuttings & 28.018316 & -82.442439 & SULPHUR SPRINGS & 25 & 20 \\
\hline 146 & W-5673 & FGS & Cuttings & 28.261349 & -82.700098 & PORT RICHEY & 19 & 120 \\
\hline 147 & W-5697 & FGS & Cuttings & 28.059326 & -82.456373 & SULPHUR SPRINGS & 39 & 656 \\
\hline 148 & W-5760 & FGS & Cuttings & 28.378764 & -82.192620 & LACOOCHEE & 95 & 109 \\
\hline 149 & W-5829 & FGS & Cuttings & 28.372441 & -82.672158 & PORT RICHEY & 25 & 75 \\
\hline 150 & W-5865 & FGS & Cuttings & 28.319424 & -82.271194 & SAN ANTONIO & 126 & 600 \\
\hline 151 & W-5866 & FGS & Cuttings & 28.392298 & -82.272286 & SPRING LAKE & 159 & 565 \\
\hline 152 & W-5942 & FGS & Cuttings & 28.393230 & -82.277416 & SPRING LAKE & 212 & 610 \\
\hline 153 & W-5949 & FGS & Cuttings & 28.054915 & -82.439341 & SULPHUR SPRINGS & 32 & 120 \\
\hline 154 & W-5952 & FGS & Cuttings & 28.043229 & -82.025975 & PLANT CITY EAST & 125 & 628 \\
\hline 155 & W-5989 & FGS & Cuttings & 28.052731 & -82.375112 & SULPHUR SPRINGS & 36 & 465 \\
\hline 156 & W-6014 & FGS & Cuttings & 28.066388 & -82.636666 & OLDSMAR & 17 & 807 \\
\hline 157 & W-6098 & FGS & Cuttings & 28.106938 & -82.640950 & OLDSMAR & 25 & 1138 \\
\hline 158 & W-6128 & FGS & Cuttings & 28.041611 & -82.387382 & SULPHUR SPRINGS & 56 & 318 \\
\hline 159 & W-6251 & FGS & Cuttings & 28.047322 & -82.393079 & SULPHUR SPRINGS & 72 & 153 \\
\hline 160 & W-6314 & FGS & Cuttings & 28.364168 & -82.184429 & DADE CITY & 76 & 140 \\
\hline 161 & W-6323 & FGS & Cuttings & 28.187064 & -82.728618 & ELFERS & 15 & 100 \\
\hline 162 & W-6399 & FGS & Cuttings & 28.061676 & -82.321233 & THONOTOSASSA & 43 & 135 \\
\hline 163 & W-6470 & FGS & Cuttings & 28.464902 & -82.194304 & LACOOCHEE & 71 & 145 \\
\hline 164 & W-6482 & FGS & Cuttings & 28.175995 & -82.734801 & ELFERS & 14 & 100 \\
\hline 165 & W-6504 & FGS & Cuttings & 28.351763 & -82.205225 & DADE CITY & 135 & 218 \\
\hline 166 & W-6556 & FGS & Cuttings & 28.479999 & -82.320829 & SPRING LAKE & 106 & 223 \\
\hline 167 & W-6627 & FGS & Cuttings & 28.471969 & -82.442656 & MASARYKTOWN & 58 & 158.5 \\
\hline 168 & W-7403 & FGS & Cuttings & 28.279680 & -82.623991 & FIVAY JUNCTION & 32 & 115 \\
\hline 169 & W-7405 & FGS & Cuttings & 28.330364 & -82.556071 & FIVAY JUNCTION & 49 & 73 \\
\hline 170 & W-7409 & FGS & Cuttings & 28.128525 & -82.452756 & LUTZ & 66 & 300 \\
\hline 171 & W-7411 & FGS & Cuttings & 28.206398 & -82.659263 & ELFERS & 36 & 301 \\
\hline 172 & W-7414 & FGS & Cuttings & 28.195565 & -82.512871 & ODESSA & 58 & 69 \\
\hline 173 & W-7418 & FGS & Cuttings & 28.195565 & -82.512871 & ODESSA & 58 & 345 \\
\hline 174 & W-7419 & FGS & Cuttings & 28.323745 & -82.356213 & SAN ANTONIO & 90 & 113 \\
\hline 175 & W-7463 & FGS & Cuttings & 28.427374 & -82.466196 & MASARYKTOWN & 66 & 81.5 \\
\hline 176 & W-7464 & FGS & Cuttings & 28.337411 & -82.626625 & PORT RICHEY & 31 & 73 \\
\hline 177 & W-7465 & FGS & Cuttings & 28.321948 & -82.445925 & EHREN & 80 & 73 \\
\hline
\end{tabular}


OPEN-FILE REPORT 98

\begin{tabular}{|c|c|c|c|c|c|c|c|c|}
\hline $\begin{array}{l}\text { Map } \\
\text { ID }\end{array}$ & Well Label & Data Source & Sample Type & Latitude & Longitude & 24K Quad & $\begin{array}{c}\text { Elevation } \\
(\mathrm{ft})\end{array}$ & $\begin{array}{c}\text { Total } \\
\text { Depth }(\mathrm{ft})\end{array}$ \\
\hline 178 & W-7466 & FGS & Cuttings & 28.287782 & -82.278696 & SAN ANTONIO & 129 & 150 \\
\hline 179 & W-7647 & FGS & Cuttings & 28.179665 & -82.731911 & ELFERS & 27 & 109 \\
\hline 180 & W-7652 & FGS & Cuttings & 28.009276 & -82.534613 & CITRUS PARK & 27 & 41 \\
\hline 181 & W-7674 & FGS & Cuttings & 28.337561 & -82.235058 & DADE CITY & 106 & 280 \\
\hline 182 & W-7732 & FGS & Cuttings & 28.484946 & -82.173618 & LACOOCHEE & 71 & 185 \\
\hline 183 & W-7762 & FGS & Cuttings & 28.451019 & -82.662566 & ARIPEKA & 1 & 195 \\
\hline 184 & W-7763 & FGS & Cuttings & 28.452780 & -82.650651 & ARIPEKA & 7 & 246 \\
\hline 185 & W-7801 & FGS & Cuttings & 28.454740 & -82.086178 & CLAY SINK & 76 & 86 \\
\hline 186 & W-7828 & FGS & Cuttings & 28.443661 & -82.370354 & SPRING LAKE & 100 & 72 \\
\hline 187 & W-8040 & FGS & Cuttings & 28.457462 & -82.611027 & PORT RICHEY NE & 30 & 200 \\
\hline 188 & W-8124 & FGS & Cuttings & 28.004164 & -82.660514 & OLDSMAR & 6 & 175 \\
\hline 189 & W-8125 & FGS & Cuttings & 28.004164 & -82.660514 & OLDSMAR & 6 & 45 \\
\hline 190 & W-8168 & FGS & Cuttings & 28.456485 & -82.611971 & PORT RICHEY NE & 34 & 373 \\
\hline 191 & W-8197 & FGS & Cuttings & 28.015828 & -82.604224 & CITRUS PARK & 9 & 184 \\
\hline 192 & W-8318 & FGS & Cuttings & 28.355554 & -82.475312 & EHREN & 67 & 610 \\
\hline 193 & W-8357 & FGS & Cuttings & 28.442469 & -82.372609 & SPRING LAKE & 98 & 285 \\
\hline 194 & W-8488 & FGS & Cuttings & 28.204864 & -82.743439 & ELFERS & 20 & 65 \\
\hline 195 & W-8507 & FGS & Cuttings & 28.352239 & -82.280615 & SAN ANTONIO & 185 & 345 \\
\hline 196 & W-8572 & FGS & Cuttings & 28.017812 & -82.398651 & SULPHUR SPRINGS & 32 & 222 \\
\hline 197 & W-10296 & FGS & Cuttings & 28.299349 & -82.701391 & PORT RICHEY & 19 & 125 \\
\hline 198 & W-10298 & FGS & Cuttings & 28.472777 & -82.251388 & SPRING LAKE & 105 & 100 \\
\hline 199 & W-10352 & FGS & Cuttings & 28.446585 & -82.606778 & PORT RICHEY NE & 24 & 286 \\
\hline 200 & W-10356 & FGS & Cuttings & 28.455613 & -82.608865 & PORT RICHEY NE & 36 & 354 \\
\hline 201 & W-10357 & FGS & Cuttings & 28.470139 & -82.526921 & PORT RICHEY NE & 59 & 335 \\
\hline 202 & W-10467 & FGS & Cuttings & 28.487612 & -82.197407 & LACOOCHEE & 58 & 65 \\
\hline 203 & W-10468 & FGS & Core & 28.374258 & -82.682916 & PORT RICHEY & 9 & 178 \\
\hline 204 & W-10505 & FGS & Cuttings & 28.045770 & -82.333951 & THONOTOSASSA & 50 & 78 \\
\hline 205 & W-10576 & FGS & Cuttings & 28.017811 & -82.195322 & PLANT CITY WEST & 99 & 400 \\
\hline 206 & W-10596 & FGS & Cuttings & 28.178947 & -82.179995 & ZEPHYRHILLS & 63 & 125 \\
\hline 207 & W-10609 & FGS & Cuttings & 28.019315 & -82.755045 & DUNEDIN & 49 & 340 \\
\hline 208 & W-10610 & FGS & Cuttings & 28.019315 & -82.755045 & DUNEDIN & 49 & 260 \\
\hline 209 & W-10612 & FGS & Cuttings & 28.019315 & -82.755045 & DUNEDIN & 49 & 175 \\
\hline 210 & W-10726 & FGS & Cuttings & 28.060626 & -82.295075 & THONOTOSASSA & 53 & 145 \\
\hline 211 & W-10727 & FGS & Cuttings & 28.189856 & -82.464889 & LUTZ & 67 & 94 \\
\hline 212 & W-10740 & FGS & Cuttings & 28.371399 & -82.357138 & SAN ANTONIO & 124 & 180 \\
\hline 213 & W-10742 & FGS & Cuttings & 28.423600 & -82.191413 & LACOOCHEE & 85 & 195 \\
\hline 214 & W-10744 & FGS & Cuttings & 28.350494 & -82.232921 & DADE CITY & 134 & 160 \\
\hline 215 & W-11052 & FGS & Cuttings & 28.331156 & -82.221661 & DADE CITY & 83 & 80 \\
\hline 216 & W-11097 & FGS & Cuttings & 28.043595 & -82.501475 & CITRUS PARK & 39 & 530 \\
\hline 217 & W-11121 & FGS & Cuttings & 28.499289 & -82.559437 & PORT RICHEY NE & 35 & 418 \\
\hline 218 & W-11194 & FGS & Cuttings & 28.028219 & -82.155458 & PLANT CITY WEST & 115 & 190 \\
\hline 219 & W-11221 & FGS & Cuttings & 28.209651 & -82.739950 & ELFERS & 16 & 57 \\
\hline 220 & W-11222 & FGS & Cuttings & 28.485999 & -82.327824 & SPRING LAKE & 102 & 280 \\
\hline 221 & W-11262 & FGS & Cuttings & 28.485740 & -82.054699 & CLAY SINK & 90 & 60 \\
\hline 222 & W-11268 & FGS & Cuttings & 28.187578 & -82.467658 & LUTZ & 72 & 213 \\
\hline 223 & W-11297 & FGS & Cuttings & 28.280926 & -82.179742 & DADE CITY & 82 & 265 \\
\hline 224 & W-11337 & FGS & Cuttings & 28.019444 & -82.341944 & THONOTOSASSA & 15 & 332 \\
\hline 225 & W-11362 & FGS & Cuttings & 28.368664 & -82.278611 & SAN ANTONIO & 146 & 760 \\
\hline 226 & W-11364 & FGS & Cuttings & 28.397618 & -82.344375 & SPRING LAKE & 132 & 360 \\
\hline 227 & W-11431 & FGS & Cuttings & 28.324051 & -82.690986 & PORT RICHEY & 22 & 127 \\
\hline 228 & W-11433 & FGS & Cuttings & 28.061951 & -82.459314 & SULPHUR SPRINGS & 39 & 402 \\
\hline 229 & W-11434 & FGS & Cuttings & 28.076952 & -82.492184 & SULPHUR SPRINGS & 53 & 440 \\
\hline 230 & W-11493 & FGS & Cuttings & 28.324028 & -82.707355 & PORT RICHEY & 3 & 115 \\
\hline 231 & W-11563 & FGS & Cuttings & 28.325118 & -82.324829 & SAN ANTONIO & 96 & 240 \\
\hline 232 & W-11588 & FGS & Cuttings & 28.331237 & -82.641717 & PORT RICHEY & 29 & 110 \\
\hline 233 & W-11663 & FGS & Cuttings & 28.222742 & -82.476953 & LUTZ & 75 & 130 \\
\hline 234 & W-11779 & FGS & Cuttings & 28.383345 & -82.195695 & LACOOCHEE & 88 & 110 \\
\hline 235 & W-11781 & FGS & Cuttings & 28.204018 & -82.738354 & ELFERS & 9 & 108 \\
\hline 236 & W-11787 & FGS & Cuttings & 28.062106 & -82.508797 & CITRUS PARK & 44 & 500 \\
\hline 237 & W-11791 & FGS & Cuttings & 28.265958 & -82.674397 & PORT RICHEY & 23 & 220 \\
\hline 238 & W-11814 & FGS & Cuttings & 28.033184 & -82.187817 & PLANT CITY WEST & 94 & 200 \\
\hline
\end{tabular}


FLORIDA GEOLOGICAL SURVEY

\begin{tabular}{|c|c|c|c|c|c|c|c|c|}
\hline $\begin{array}{l}\text { Map } \\
\text { ID }\end{array}$ & Well Label & Data Source & Sample Type & Latitude & Longitude & 24K Quad & $\begin{array}{c}\text { Elevation } \\
(\mathrm{ft})\end{array}$ & $\begin{array}{c}\text { Total } \\
\text { Depth }(\mathrm{ft})\end{array}$ \\
\hline 239 & W-11825 & FGS & Cuttings & 28.180416 & -82.608658 & ODESSA & 41 & 100 \\
\hline 240 & W-11924 & FGS & Cuttings & 28.049960 & -82.339044 & THONOTOSASSA & 48 & 162 \\
\hline 241 & W-12062 & FGS & Cuttings & 28.339495 & -82.212339 & DADE CITY & 126 & 309 \\
\hline 242 & W-12119 & FGS & Cuttings & 28.019315 & -82.755045 & DUNEDIN & 49 & 290 \\
\hline 243 & W-12121 & FGS & Cuttings & 28.019315 & -82.755045 & DUNEDIN & 49 & 290 \\
\hline 244 & W-12122 & FGS & Cuttings & 28.019315 & -82.755045 & DUNEDIN & 49 & 270 \\
\hline 245 & W-12124 & FGS & Cuttings & 28.065463 & -82.753918 & DUNEDIN & 58 & 250 \\
\hline 246 & W-12381 & FGS & Cuttings & 28.057495 & -82.424197 & SULPHUR SPRINGS & 38 & 230 \\
\hline 247 & W-12457 & FGS & Cuttings & 28.006910 & -82.343907 & THONOTOSASSA & 23 & 101 \\
\hline 248 & W-12536 & FGS & Cuttings & 28.272452 & -82.173070 & DADE CITY & 86 & 140 \\
\hline 249 & W-12604 & FGS & Cuttings & 28.003370 & -82.178760 & PLANT CITY WEST & 104 & 307 \\
\hline 250 & W-12607 & FGS & Cuttings & 28.003370 & -82.178760 & PLANT CITY WEST & 104 & 325 \\
\hline 251 & W-12779 & FGS & Cuttings & 28.237071 & -82.229775 & ZEPHYRHILLS & 87 & 80 \\
\hline 252 & W-12828 & FGS & Cuttings & 28.299499 & -82.380218 & EHREN & 69 & 700 \\
\hline 253 & W-12829 & FGS & Cuttings & 28.304607 & -82.380367 & EHREN & 72 & 700 \\
\hline 254 & W-12830 & FGS & Cuttings & 28.278260 & -82.401478 & EHREN & 62 & 700 \\
\hline 255 & W-12863 & FGS & Cuttings & 28.313252 & -82.686899 & PORT RICHEY & 26 & 100 \\
\hline 256 & W-12943 & FGS & Cuttings & 28.107718 & -82.757750 & DUNEDIN & 15 & 3000 \\
\hline 257 & W-12944 & FGS & Cuttings & 28.105787 & -82.459458 & SULPHUR SPRINGS & 60 & 145 \\
\hline 258 & W-12949 & FGS & Cuttings & 28.022416 & -82.285035 & THONOTOSASSA & 63 & 300 \\
\hline 259 & W-12962 & FGS & Core & 28.262973 & -82.018844 & BRANCHBOROUGH & 97 & 7.1 \\
\hline 260 & W-12964 & FGS & Core & 28.266388 & -82.019444 & BRANCHBOROUGH & 93 & 100 \\
\hline 261 & W-12965 & FGS & Core & 28.298650 & -82.019039 & BRANCHBOROUGH & 90 & 100 \\
\hline 262 & W-12966 & FGS & Core & 28.291668 & -82.011080 & BRANCHBOROUGH & 96 & 100 \\
\hline 263 & W-12967 & FGS & Core & 28.262231 & -82.011011 & BRANCHBOROUGH & 98 & 100 \\
\hline 264 & W-12991 & FGS & Cuttings & 28.297416 & -82.384507 & EHREN & 67 & 491 \\
\hline 265 & W-13180 & FGS & Cuttings & 28.035199 & -82.032485 & PLANT CITY EAST & 125 & 260 \\
\hline 266 & W-13185 & FGS & Cuttings & 28.009679 & -82.504605 & CITRUS PARK & 38 & 140 \\
\hline 267 & W-13252 & FGS & Cuttings & 28.105721 & -82.344163 & THONOTOSASSA & 33 & 608 \\
\hline 268 & W-13255 & FGS & Cuttings & 28.120147 & -82.327930 & THONOTOSASSA & 34 & 580 \\
\hline 269 & W-13257 & FGS & Cuttings & 28.105649 & -82.327729 & THONOTOSASSA & 31 & 620 \\
\hline 270 & W-13258 & FGS & Cuttings & 28.105721 & -82.344163 & THONOTOSASSA & 33 & 600 \\
\hline 271 & W-13259 & FGS & Cuttings & 28.105721 & -82.344163 & THONOTOSASSA & 33 & 542 \\
\hline 272 & W-13260 & FGS & Cuttings & 28.120176 & -82.311541 & THONOTOSASSA & 35 & 600 \\
\hline 273 & W-13261 & FGS & Cuttings & 28.120201 & -82.344394 & THONOTOSASSA & 42 & 610 \\
\hline 274 & W-13263 & FGS & Cuttings & 28.120147 & -82.327930 & THONOTOSASSA & 34 & 550 \\
\hline 275 & W-13264 & FGS & Cuttings & 28.120201 & -82.344394 & THONOTOSASSA & 42 & 573 \\
\hline 276 & W-13290 & FGS & Cuttings & 28.076952 & -82.492184 & SULPHUR SPRINGS & 53 & 350 \\
\hline 277 & W-13292 & FGS & Cuttings & 28.470144 & -82.444719 & MASARYKTOWN & 67 & 330 \\
\hline 278 & W-13410 & FGS & Cuttings & 28.181913 & -82.186195 & ZEPHYRHILLS & 53 & 105 \\
\hline 279 & W-13428 & FGS & Cuttings & 28.251506 & -82.188815 & DADE CITY & 90 & 132 \\
\hline 280 & W-13436 & FGS & Cuttings & 28.016683 & -82.507153 & CITRUS PARK & 34 & 140 \\
\hline 281 & W-13444 & FGS & Cuttings & 28.293644 & -82.388674 & EHREN & 71 & 521 \\
\hline 282 & W-13581 & FGS & Cuttings & 28.180328 & -82.789059 & TARPON SPRINGS & 17 & 142 \\
\hline 283 & W-13582 & FGS & Cuttings & 28.204747 & -82.772854 & TARPON SPRINGS & 9 & 70 \\
\hline 284 & W-13681 & FGS & Cuttings & 28.335895 & -82.663095 & PORT RICHEY & 15 & 80 \\
\hline 285 & W-13717 & FGS & Cuttings & 28.062110 & -82.132950 & PLANT CITY WEST & 104 & 68 \\
\hline 286 & W-13743 & FGS & Cuttings & 28.446861 & -82.288210 & SPRING LAKE & 89 & 170 \\
\hline 287 & W-13799 & FGS & Cuttings & 28.386540 & -82.477260 & MASARYKTOWN & 68 & 700 \\
\hline 288 & W-13802 & FGS & Cuttings & 28.362792 & -82.471214 & EHREN & 75 & 700 \\
\hline 289 & W-13899 & FGS & Cuttings & 28.361853 & -82.476340 & EHREN & 74 & 700 \\
\hline 290 & W-13900 & FGS & Cuttings & 28.377454 & -82.471095 & MASARYKTOWN & 62 & 490 \\
\hline 291 & W-13901 & FGS & Cuttings & 28.420095 & -82.511463 & PORT RICHEY NE & 66 & 640 \\
\hline 292 & W-13909 & FGS & Cuttings & 28.412503 & -82.245124 & LACOOCHEE & 104 & 140 \\
\hline 293 & W-13923 & FGS & Cuttings & 28.246397 & -82.594539 & ODESSA & 45 & 905 \\
\hline 294 & W-13924 & FGS & Cuttings & 28.246397 & -82.595095 & ODESSA & 50 & 905 \\
\hline 295 & W-13944 & FGS & Cuttings & 28.105650 & -82.311400 & THONOTOSASSA & 31 & 520 \\
\hline 296 & W-13970 & FGS & Cuttings & 28.397429 & -82.543230 & PORT RICHEY NE & 66 & 502 \\
\hline 297 & W-13973 & FGS & Cuttings & 28.397429 & -82.543230 & PORT RICHEY NE & 66 & 700 \\
\hline 298 & W-14016 & FGS & Cuttings & 28.003061 & -82.211938 & PLANT CITY WEST & 132 & 150 \\
\hline 299 & W-14046 & FGS & Cuttings & 28.338909 & -82.608404 & FIVAY JUNCTION & 30 & 515 \\
\hline
\end{tabular}


OPEN-FILE REPORT 98

\begin{tabular}{|c|c|c|c|c|c|c|c|c|}
\hline $\begin{array}{l}\text { Map } \\
\text { ID }\end{array}$ & Well Label & Data Source & Sample Type & Latitude & Longitude & 24K Quad & $\begin{array}{c}\text { Elevation } \\
(\mathrm{ft})\end{array}$ & $\begin{array}{c}\text { Total } \\
\text { Depth }(\mathrm{ft})\end{array}$ \\
\hline 300 & W-14128 & FGS & Cuttings & 28.045470 & -82.337683 & THONOTOSASSA & 43 & 262 \\
\hline 301 & W-14168 & FGS & Cuttings & 28.123531 & -82.225369 & PLANT CITY WEST & 51 & 1050 \\
\hline 302 & W-14201 & FGS & Cuttings & 28.239561 & -82.206073 & ZEPHYRHILLS & 84 & 180 \\
\hline 303 & W-14220 & FGS & Cuttings & 28.417537 & -82.454818 & MASARYKTOWN & 63 & 706 \\
\hline 304 & W-14350 & FGS & Cuttings & 28.391169 & -82.472204 & MASARYKTOWN & 68 & 705 \\
\hline 305 & W-14351 & FGS & Cuttings & 28.411258 & -82.461817 & MASARYKTOWN & 62 & 700 \\
\hline 306 & W-14352 & FGS & Cuttings & 28.360166 & -82.455626 & EHREN & 76 & 702 \\
\hline 307 & W-14589 & FGS & Cuttings & 28.298227 & -82.373373 & SAN ANTONIO & 71 & 705 \\
\hline 308 & W-14590 & FGS & Cuttings & 28.298227 & -82.373373 & SAN ANTONIO & 71 & 705 \\
\hline 309 & W-14591 & FGS & Cuttings & 28.300056 & -82.385599 & EHREN & 70 & 705 \\
\hline 310 & W-14592 & FGS & Cuttings & 28.296317 & -82.379473 & EHREN & 68 & 703 \\
\hline 311 & W-14596 & FGS & Cuttings & 28.373295 & -82.468113 & EHREN & 74 & 700 \\
\hline 312 & W-14673 & FGS & Cuttings & 28.434935 & -82.582703 & PORT RICHEY NE & 31 & 355 \\
\hline 313 & W-14674 & FGS & Cuttings & 28.321420 & -82.701861 & PORT RICHEY & 10 & 139 \\
\hline 314 & W-14675 & FGS & Cuttings & 28.322365 & -82.677853 & PORT RICHEY & 29 & 196.5 \\
\hline 315 & W-14694 & FGS & Cuttings & 28.064671 & -82.394220 & SULPHUR SPRINGS & 45 & 213 \\
\hline 316 & W-14706 & FGS & Cuttings & 28.233402 & -82.680341 & ELFERS & 22 & 315 \\
\hline 317 & W-14743 & FGS & Cuttings & 28.398428 & -82.444837 & MASARYKTOWN & 70 & 710 \\
\hline 318 & W-14794 & FGS & Cuttings & 28.404503 & -82.463797 & MASARYKTOWN & 66 & 710 \\
\hline 319 & W-14796 & FGS & Cuttings & 28.411762 & -82.458779 & MASARYKTOWN & 58 & 630 \\
\hline 320 & W-14801 & FGS & Cuttings & 28.485680 & -82.046637 & CLAY SINK & 90 & 225 \\
\hline 321 & W-14887 & FGS & Cuttings & 28.084166 & -82.243611 & PLANT CITY WEST & 51 & 490 \\
\hline 322 & W-14889 & FGS & Cuttings & 28.220138 & -82.023408 & SOCRUM & 107 & 380 \\
\hline 323 & W-14904 & FGS & Cuttings & 28.385554 & -82.468874 & MASARYKTOWN & 75 & 710 \\
\hline 324 & W-14910 & FGS & Cuttings & 28.365461 & -82.466822 & EHREN & 74 & 705 \\
\hline 325 & W-14911 & FGS & Cuttings & 28.376273 & -82.477514 & MASARYKTOWN & 70 & 700 \\
\hline 326 & W-14998 & FGS & Cuttings & 28.411913 & -82.477472 & MASARYKTOWN & 63 & 143 \\
\hline 327 & W-15000 & FGS & Cuttings & 28.236782 & -82.328499 & WESLEY CHAPEL & 92 & 590 \\
\hline 328 & W-15059 & FGS & Cuttings & 28.136040 & -82.558906 & ODESSA & 51 & 700 \\
\hline 329 & W-15070 & FGS & Cuttings & 28.024859 & -82.748931 & OLDSMAR & 64 & 255 \\
\hline 330 & W-15071 & FGS & Cuttings & 28.026365 & -82.731031 & OLDSMAR & 83 & 245 \\
\hline 331 & W-15074 & FGS & Cuttings & 28.222736 & -82.460637 & LUTZ & 72 & 163 \\
\hline 332 & W-15146 & FGS & Cuttings & 28.003440 & -82.492631 & SULPHUR SPRINGS & 37 & 263 \\
\hline 333 & W-15199 & FGS & Cuttings & 28.180340 & -82.592320 & ODESSA & 49 & 212 \\
\hline 334 & W-15200 & FGS & Cuttings & 28.396821 & -82.657937 & ARIPEKA & 21 & 90 \\
\hline 335 & W-15202 & FGS & Cuttings & 28.470153 & -82.543139 & PORT RICHEY NE & 51 & 290.5 \\
\hline 336 & W-15204 & FGS & Core & 28.025561 & -82.757781 & DUNEDIN & 55 & 604 \\
\hline 337 & W-15295 & FGS & Cuttings & 28.241742 & -82.579880 & ODESSA & 44 & 770 \\
\hline 338 & W-15296 & FGS & Cuttings & 28.254979 & -82.653486 & PORT RICHEY & 25 & 855 \\
\hline 339 & W-15298 & FGS & Cuttings & 28.249035 & -82.563494 & ODESSA & 45 & 770 \\
\hline 340 & W-15324 & FGS & Cuttings & 28.070897 & -82.444834 & SULPHUR SPRINGS & 43 & 145 \\
\hline 341 & W-15331 & FGS & Cuttings & 28.194756 & -82.592408 & ODESSA & 57 & 340 \\
\hline 342 & W-15345 & FGS & Cuttings & 28.026881 & -82.248081 & PLANT CITY WEST & 56 & 420 \\
\hline 343 & W-15385 & FGS & Cuttings & 28.002814 & -82.727442 & OLDSMAR & 92 & 260 \\
\hline 344 & W-15387 & FGS & Cuttings & 28.006508 & -82.727469 & OLDSMAR & 90 & 275 \\
\hline 345 & W-15463 & FGS & Cuttings & 28.166133 & -82.675585 & ELFERS & 24 & 780 \\
\hline 346 & W-15466 & FGS & Cuttings & 28.092970 & -82.657226 & OLDSMAR & 19 & 850 \\
\hline 347 & W-15585 & FGS & Core & 28.460468 & -82.085710 & CLAY SINK & 78 & 49 \\
\hline 348 & W-15586 & FGS & Core & 28.402260 & -82.087598 & CLAY SINK & 82 & 28.6 \\
\hline 349 & W-15587 & FGS & Core & 28.419018 & -82.116717 & CLAY SINK & 70 & 28.6 \\
\hline 350 & W-15591 & FGS & Core & 28.442222 & -82.050635 & CLAY SINK & 90 & 99 \\
\hline 351 & W-15595 & FGS & Core & 28.407658 & -82.000752 & CLAY SINK & 92 & 21.27 \\
\hline 352 & W-15647 & FGS & Cuttings & 28.360051 & -82.141997 & DADE CITY & 75 & 665 \\
\hline 353 & W-15684 & FGS & Cuttings & 28.256294 & -82.710471 & PORT RICHEY & 20 & 310 \\
\hline 354 & W-15802 & FGS & Cuttings & 28.436521 & -82.638713 & ARIPEKA & 18 & 805 \\
\hline 355 & W-15917 & FGS & Core & 28.341108 & -82.438310 & EHREN & 77 & 65 \\
\hline 356 & W-15918 & FGS & Core & 28.304309 & -82.450159 & EHREN & 80 & 65 \\
\hline 357 & W-15919 & FGS & Core & 28.337340 & -82.413531 & EHREN & 77 & 65 \\
\hline 358 & W-15920 & FGS & Core & 28.362954 & -82.413575 & EHREN & 78 & 65 \\
\hline 359 & W-15976 & FGS & Cuttings & 28.203137 & -82.375767 & LUTZ & 53 & 700 \\
\hline 360 & W-15977 & FGS & Cuttings & 28.203137 & -82.375767 & LUTZ & 53 & 700 \\
\hline
\end{tabular}


FLORIDA GEOLOGICAL SURVEY

\begin{tabular}{|c|c|c|c|c|c|c|c|c|}
\hline $\begin{array}{l}\text { Map } \\
\text { ID }\end{array}$ & Well Label & Data Source & Sample Type & Latitude & Longitude & 24K Quad & $\begin{array}{c}\text { Elevation } \\
\text { (ft) }\end{array}$ & $\begin{array}{c}\text { Total } \\
\text { Depth }(\mathrm{ft})\end{array}$ \\
\hline 361 & W-15993 & FGS & Core & 28.286118 & -82.194237 & DADE CITY & 203 & 162 \\
\hline 362 & W-16312 & FGS & Core & 28.468315 & -82.446780 & MASARYKTOWN & 68 & 20 \\
\hline 363 & W-16313 & FGS & Core & 28.468315 & -82.446780 & MASARYKTOWN & 68 & 27.5 \\
\hline 364 & W-16314 & FGS & Core & 28.468315 & -82.446780 & MASARYKTOWN & 68 & 23 \\
\hline 365 & W-16315 & FGS & Core & 28.468315 & -82.446780 & MASARYKTOWN & 68 & 25 \\
\hline 366 & W-16418 & FGS & Cuttings & 28.083333 & -82.526388 & CITRUS PARK & 46 & 40 \\
\hline 367 & W-16419 & FGS & Cuttings & 28.072222 & -82.551388 & CITRUS PARK & 34 & 119 \\
\hline 368 & W-16420 & FGS & Cuttings & 28.097222 & -82.522777 & CITRUS PARK & 49 & 45 \\
\hline 369 & W-16427 & FGS & Cuttings & 28.036111 & -82.487499 & SULPHUR SPRINGS & 8 & 25 \\
\hline 370 & W-16428 & FGS & Cuttings & 28.052777 & -82.486111 & SULPHUR SPRINGS & 33 & 70 \\
\hline 371 & W-16463 & FGS & Cuttings & 28.029166 & -82.488333 & SULPHUR SPRINGS & 42 & 62 \\
\hline 372 & W-16467 & FGS & Core & 28.000277 & -82.561944 & GANDY BRIDGE & 1 & 31 \\
\hline 373 & W-16468 & FGS & Core & 28.036668 & -82.568331 & CITRUS PARK & 21 & 51 \\
\hline 374 & W-16473 & FGS & Core & 28.102222 & -82.641944 & OLDSMAR & 25 & 60 \\
\hline 375 & W-16474 & FGS & Core & 28.191537 & -82.480197 & LUTZ & 66 & 71 \\
\hline 376 & W-16476 & FGS & Core & 28.161111 & -82.596388 & ODESSA & 48 & 51 \\
\hline 377 & W-16477 & FGS & Core & 28.213897 & -82.516221 & ODESSA & 59 & 55 \\
\hline 378 & W-16480 & FGS & Core & 28.156769 & -82.727160 & ELFERS & 2 & 74 \\
\hline 379 & W-16481 & FGS & Core & 28.153333 & -82.476111 & LUTZ & 64 & 70 \\
\hline 380 & W-16482 & FGS & Core & 28.015833 & -82.636111 & OLDSMAR & 5 & 65 \\
\hline 381 & W-16483 & FGS & Core & 28.000833 & -82.720000 & OLDSMAR & 90 & 124 \\
\hline 382 & W-16484 & FGS & Core & 28.032777 & -82.721944 & OLDSMAR & 92 & 130 \\
\hline 383 & W-16486 & FGS & Core & 28.089722 & -82.735833 & OLDSMAR & 66 & 122 \\
\hline 384 & W-16490 & FGS & Core & 28.046111 & -82.643333 & OLDSMAR & 7 & 60 \\
\hline 385 & W-16494 & FGS & Core & 28.161099 & -82.446899 & LUTZ & 64 & 73 \\
\hline 386 & W-16495 & FGS & Core & 28.211587 & -82.713304 & ELFERS & 40 & 98 \\
\hline 387 & W-16496 & FGS & Core & 28.207644 & -82.681360 & ELFERS & 25 & 68 \\
\hline 388 & W-16575 & FGS & Cuttings & 28.069891 & -82.611756 & CITRUS PARK & 24 & 1285 \\
\hline 389 & W-16609 & FGS & Core & 28.240459 & -82.709678 & ELFERS & 7 & 549 \\
\hline 390 & W-16658 & FGS & Cuttings & 28.021168 & -82.422531 & SULPHUR SPRINGS & 32 & 800 \\
\hline 391 & W-17081 & FGS & Cuttings & 28.032447 & -82.211868 & PLANT CITY WEST & 77 & 500 \\
\hline 392 & W-17343 & FGS & Cuttings & 28.219999 & -82.021111 & SOCRUM & 107 & 40 \\
\hline 393 & W-17598 & FGS & Cuttings & 28.111111 & -82.486944 & SULPHUR SPRINGS & 48 & 104 \\
\hline 394 & W-17687 & FGS & Cuttings & 28.024722 & -82.609444 & CITRUS PARK & 6 & 460 \\
\hline 395 & W-17998 & FGS & Core & 28.164456 & -82.105078 & SOCRUM & 94 & 197 \\
\hline 396 & W-17999 & FGS & Core & 28.160290 & -82.070633 & SOCRUM & 106 & 195 \\
\hline 397 & W-18000 & FGS & Core & 28.152512 & -82.090356 & SOCRUM & 98 & 195 \\
\hline 398 & W-18001 & FGS & Core & 28.139457 & -82.107856 & SOCRUM & 91 & 175 \\
\hline 399 & W-18002 & FGS & Core & 28.132095 & -82.121878 & SOCRUM & 87 & 175 \\
\hline 400 & W-18019 & FGS & Core & 28.099379 & -82.102733 & PLANT CITY EAST & 100 & 195 \\
\hline 401 & W-18022 & FGS & Core & 28.098348 & -82.080633 & PLANT CITY EAST & 108 & 195 \\
\hline 402 & W-18049 & FGS & Cuttings & 28.008333 & -82.478888 & SULPHUR SPRINGS & 27 & 430 \\
\hline 403 & W-18055 & FGS & Cuttings & 28.462498 & -82.633886 & ARIPEKA & 15 & 800 \\
\hline 404 & W-18056 & FGS & Cuttings & 28.003055 & -82.484444 & SULPHUR SPRINGS & 34 & 430 \\
\hline 405 & W-18118 & FGS & Core & 28.488885 & -82.323700 & SPRING LAKE & 155 & 1373 \\
\hline 406 & W-18147 & FGS & Core & 28.194176 & -82.200359 & ZEPHYRHILLS & 66 & 99 \\
\hline 407 & W-18148 & FGS & Core & 28.175566 & -82.121468 & SOCRUM & 89 & 104 \\
\hline 408 & W-18149 & FGS & Core & 28.260937 & -82.218842 & DADE CITY & 102 & 34 \\
\hline 409 & W-18151 & FGS & Core & 28.251770 & -82.245945 & DADE CITY & 110 & 99 \\
\hline 410 & W-18154 & FGS & Core & 28.458060 & -82.655914 & ARIPEKA & 5 & 43 \\
\hline 411 & W-18620 & FGS & Cuttings & 28.005573 & -82.425645 & SULPHUR SPRINGS & 40 & 353 \\
\hline 412 & W-18723 & FGS & Cuttings & 28.172233 & -82.770932 & TARPON SPRINGS & 12 & 120 \\
\hline 413 & W-18940 & FGS & Cuttings & 28.135311 & -82.178921 & ZEPHYRHILLS & 70 & 9.5 \\
\hline 414 & W-18948 & FGS & Cuttings & 28.237528 & -82.117444 & SOCRUM & 78 & 4 \\
\hline 415 & W-18956 & FGS & Cuttings & 28.239694 & -82.134388 & ZEPHYRHILLS & 76 & 8.5 \\
\hline 416 & W-18983 & FGS & Cuttings & 28.142277 & -82.394417 & LUTZ & 37 & 8 \\
\hline 417 & W-19237 & FGS & Cuttings & 28.076528 & -82.335028 & THONOTOSASSA & 37 & 30 \\
\hline 418 & W-19252 & FGS & Cuttings & 28.029957 & -82.655268 & OLDSMAR & 6 & 450 \\
\hline
\end{tabular}

